\title{
Responses of soil respiration and its temperature/moisture sensitivity to precipitation in three subtropical forests in southern China
}

\author{
H. Jiang ${ }^{1,2}$, Q. Deng ${ }^{1,3}$, G. Zhou ${ }^{1}$, D. Hui ${ }^{4}$, D. Zhang ${ }^{1}$, S. Liu ${ }^{1}$, G. Chu ${ }^{1}$, and J. Li ${ }^{1}$ \\ ${ }^{1}$ Key Laboratory of Vegetation Restoration and Management of Degraded Ecosystems, South China Botanical Garden, \\ Chinese Academy of Sciences, Guangzhou, 510650, China \\ ${ }^{2}$ Graduate University of Chinese Academy of Sciences, Beijing, 100049, China \\ ${ }^{3}$ Key Laboratory of Aquatic Botany and Watershed Ecology, Wuhan Botanical Garden, the Chinese Academy of Sciences, \\ Wuhan 430074, China \\ ${ }^{4}$ Department of Biological Sciences, Tennessee State University, Nashville, TN 37209, USA
}

Correspondence to: Q. Deng (dengqi@scib.ac.cn)

Received: 26 October 2012 - Published in Biogeosciences Discuss.: 8 November 2012

Revised: 5 May 2013 - Accepted: 9 May 2013 - Published: 18 June 2013

\begin{abstract}
Both long-term observation data and model simulations suggest an increasing chance of serious drought in the dry season and extreme flood in the wet season in southern China, yet little is known about how changes in precipitation pattern will affect soil respiration in the region. We conducted a field experiment to study the responses of soil respiration to precipitation manipulations - precipitation exclusion to mimic drought, double precipitation to simulate flood, and ambient precipitation as control (abbr. EP, DP and AP, respectively) - in three subtropical forests in southern China. The three forest sites include Masson pine forest (PF), coniferous and broad-leaved mixed forest (MF) and monsoon evergreen broad-leaved forest (BF). Our observations showed that altered precipitation strongly influenced soil respiration, not only through the well-known direct effects of soil moisture on plant and microbial activities, but also by modification of both moisture and temperature sensitivity of soil respiration. In the dry season, soil respiration and its temperature sensitivity, as well as fine root and soil microbial biomass, showed rising trends with precipitation increases in the three forest sites. Contrarily, the moisture sensitivity of soil respiration decreased with precipitation increases. In the wet season, different treatments showed different effects in three forest sites. The EP treatment decreased fine root biomass, soil microbial biomass, soil respiration and its temperature sensitivity, but enhanced soil moisture sensitivity
\end{abstract}

in all three forest sites. The DP treatment significantly increased soil respiration, fine root and soil microbial biomass in the PF only, and no significant change was found for the soil temperature sensitivity. However, the DP treatment in the $\mathrm{MF}$ and $\mathrm{BF}$ reduced soil temperature sensitivity significantly in the wet season. Our results indicated that soil respiration would decrease in the three subtropical forests if soil moisture continues to decrease in the future. More rainfall in the wet season could have limited effect on the response of soil respiration to the rising of temperature in the $\mathrm{BF}$ and MF.

\section{Introduction}

As one of the largest carbon fluxes in terrestrial ecosystems, soil respiration has received renewed attention in recent decades due to the concerns over its potential feedback to future climate change (Trumbore, 1997; Valentini et al., 2000; Bond-Lamberty and Thompson, 2010). It is generally accepted that rising temperature would accelerate $\mathrm{CO}_{2}$ release from soils, which in return reinforces anthropogenic warming (Cox et al., 2000; Luo, 2007). Both climate models and satellite observations suggested change in precipitation patterns in the warm climate (Easterling et al., 2000; IPCC, 2007; Allan and Soden, 2008). However, our studies of precipitation impacts on soil respiration have not 
generated a definite conclusion. Precipitation manipulation experiments showed variable effects on soil respiration in different ecosystems (Borken et al., 2006; Zhou et al,. 2006; Sotta et al., 2007; Davidson et al., 2008; van Straaten et al., 2010, 2011; Cleveland et al., 2010; Talmon et al., 2011), and hence extensive research is necessary to make an accurate assessment of its global impacts.

The release of $\mathrm{CO}_{2}$ in soils is almost entirely from root respiration and microbial decomposition of organic matter (Rustad et al., 2000; Hui and Luo, 2004; Davidson and Janssens, 2006). Root activity and microbial decomposition are often subject to both environmental factors and substrate changes related to phenological processes (Orchard and Cook, 1983; Davidson et al., 1998; Högberg et al., 2001; Luo et al., 2001; Campbell et al., 2004; Curiel Yuste et al., 2004, 2007; Gaumont-Guay et al., 2006). Global and regional earth system modeling studies have identified temperature and moisture as major factors regulating soil respiration in terrestrial ecosystems (Raich and Potter, 1995; Davidson et al., 1998; Reichstein et al., 2003; Gaumont-Guay et al., 2006; Heimann and Reichstein, 2008; Medvigy et al., 2010; Falloon et al., 2011). When effects of soil temperature and moisture on soil respiration are simultaneously described, it is often assumed that their individual effects are plus, minus, and multiplicative (i.e., the product of two functions, one for each of the two variables) with the expectation that the temperature sensitivity is independent of soil moisture (e.g., Bunnell et al., 1977; Fang and Moncrieff, 2001; Reichstein et al., 2002; Luo and Zhou, 2006; Jassal et al., 2008; see Table 1). Altered precipitation may influence soil respiration through the direct effects of soil temperature and moisture change on plant and microbial activities, and/or by the indirect modification of model function (defined as changes in model parameters of soil respiration with soil temperature and moisture, or both) associated temperature and moisture sensitivity of soil respiration. Shift of soil temperature/moisture sensitivity could be also attributed to the changes in phenological process, substrate or microbial activity (Zogg et al., 1997; Luo et al., 2001; Zhang et al., 2005; Noormets et al., 2008; Deng et al., 2012).

Numerous studies have focused on the responses of soil respiration to soil temperature. While many empirical models have been developed to relate field-measured soil respiration and temperature (e.g., Lloyd and Taylor, 1994; Davidson et al., 2000; Luo and Zhou, 2006), the $Q_{10}$ model ( $R=$ $R_{0} \exp (b T)$, where $R$ is soil respiration, $T$ soil temperature, and parameter $R_{0}$ basal soil respiration when $T=0$, and $b$ is related to soil temperature sensitivity $\left(Q_{10}=\exp (10 b)\right)$ still remains the most widely used one (e.g., Cox et al., 2000; Bond-Lamberty and Thompson, 2010; see section 1 in the Table 1). Both experimental and modeling studies have shown that temperature sensitivity of soil respiration varied seasonally (Lloyd and Taylor, 1994; Xu and Qi, 2001), and decreased under warming treatment (Luo et al., 2001; Conant et al., 2008). Moreover, Davidson and Janssens (2006) reported the "intrinsic" temperature sensitivity acts this way from basic biokinetics. Thus, many ecosystems and global models tried to use variable $Q_{10}$ values with temperature (Lloyd and Taylor, 1994). Several authors indicated that seasonal variation of temperature sensitivity was also associated with soil moisture (Xu and Qi, 2001; Curiel Yuste et al., 2003; Almagro et al., 2009), but the results were mostly based on the observations of seasonal variation, which may often be confounded by other factors such as temperature and phenological processes (Luo et al., 2001; Curiel Yuste et al., 2004; Wang et al., 2010). Direct evidence of the precipitation impacts on temperature sensitivity under precipitation manipulations is still lacking (Davidson et al., 2006; Jassal et al., 2008; Craine and Gelderman, 2011; Suseela et al., 2012).

Unlike temperature, no convincible and agreeable conclusions have been drawn for the response of soil respiration to soil moisture. In general, soil respiration increases with the rising of soil moisture when soil water holding capacity is still in its lower stage, but will slow down or decrease when soil moisture increases to some degree (Ilstedt et al., 2000; Hui and Luo, 2004; Deng et al., 2011). In practice, however, probably due to the confoundedness by the seasonal correlation between soil moisture and temperature, or phenological processes, the relationships between field-measured soil respiration and soil moisture can been derived using either linear, logarithmic, hyperbolic or quadratic equation in different ecosystems (Luo and Zhou, 2006; see section 2 in the Table 1). These empirical models were often thought to be capable of extrapolating soil respiration variations under the future climate change (Falloon et al., 2011). It is still unclear whether the soil moisture functional coefficients, or soil moisture sensitivity, could remain constant under climate change, particularly precipitation treatments (Hui and Luo 2004; Liu et al., 2009; Misson et al., 2010).

While most studies of precipitation manipulation experiments were performed in either tropical and temperate forests or arid grasslands, little emphasis has been put on subtropical forest ecosystems (Borken et al., 2006; Zhou et al., 2006; Scott et al., 2007; Davidson et al., 2008; van Straaten et al., 2010, 2011; Cleveland et al., 2010; Talmon et al., 2011). To our knowledge, there is no such experiment that has been conducted in China. Being favored by the subtropical monsoon, the climate in southern China is abundant in heat, light, and water resources from April to September annually (Ding et al., 2001). Because of its unique climate regime, moist subtropical forests spread out in southern China, generate a moisture gradient and experience more pronounced dry season compared to the tropical forests (Tang et al., 2006). The strong seasonal variation of precipitation amount and varying moisture among forest soils provide an excellent opportunity for studies of how soil respiration responds to altered precipitation under different moisture conditions. In addition, long-term observation records in southern China showed that seasonal precipitation pattern and intensity have varied drastically in the past three decades, and the forest soil moisture 
has decreased significantly (Zhou et al., 2011). Model simulations in this region suggested an increasing chance of serious drought in the dry season and extreme flood in the wet season in the future (Zhou et al., 2011). The changing precipitation pattern may have a significant impact on the soil carbon emission of subtropical forests in southern China, but it has not been well studied.

We conducted a precipitation manipulation experiment in subtropical forests in southern China to study the responses of soil respiration to altered precipitation. We selected three common forests along a moisture gradient at the Dinghushan Nature Reserve (DNR), established three precipitation treatments in each forest site, and measured soil respiration. Precipitation was controlled automatically through interceptionredistribution systems to establish precipitation exclusion (EP), double precipitation (DP) treatments in addition to the ambient precipitation (AP) as a control (Borken et al., 2006; Zhou et al., 2006). Previous work in these forest sites has shown significant exponential relationships of soil respiration with soil temperature, and significant positive linear relationships of soil respiration with soil moisture even though soil moisture was relatively high in the region (Tang et al., 2006). However, precipitation manipulation with increased precipitation had no effects on soil respiration in two of the three forest sites (Deng et al., 2012). We suspected that such equally strong effects were probably due to high seasonal correlation between soil moisture and temperature or phenological processes. In this study, we focused on the seasonal responses of soil respiration to altered precipitation in the three subtropical forest sites, and fitted respiration measurements to both soil temperature and moisture for each season. We hypothesized that precipitation treatments would alter soil respiration though the effects of moisture change on plant and microbial activities. Moreover, we would test whether the responses of soil respiration to precipitation alteration varied seasonally and differed among the three forest sites. Associated with shifts in plant and microbial activities, we further hypothesized that altered precipitation would lead to functional change, and in turn modify soil moisture/temperature sensitivity in the three forest sites. More specifically, we expected that the responses of soil temperature/moisture sensitivity to precipitation treatments varied seasonally and differed among the three forest sites.

\section{Materials and methods}

\subsection{Site description}

This study was conducted at the Dinghushan Nature Reserve (DNR), located in the center of Guangdong Province in southern China $\left(112^{\circ} 13^{\prime} 39^{\prime \prime}-112^{\circ} 33^{\prime} 41^{\prime \prime} \mathrm{E}, 2^{\circ} 09^{\prime} 21^{\prime \prime}-\right.$ $23^{\circ} 11^{\prime} 30^{\prime \prime} \mathrm{N}$ ). Climate in the region is typical south subtropical monsoon climate, with mean annual temperature of $21.4^{\circ} \mathrm{C}$, and total annual precipitation of $1956 \mathrm{~mm}$, of which nearly $80 \%$ falls in the hot-humid wet/rainy season (AprilSeptember) and $20 \%$ in the dry season (October-March) (Wu et al., 1982). The bedrock is sandstone and shale. Soils are classified as Oxisols with a pH of 4.0-4.9.

Three common subtropical forest sites (at elevations ranging from 150 to $300 \mathrm{~m}$, less than $500 \mathrm{~m}$ from one another and facing the same slope direction) at the DNR were selected including a coniferous Masson pine forest (PF), a conifer and broadleaf mixed forest (MF), and a monsoon evergreen broadleaf forest (BF). The three forest sites also represented forests in early, mid-, and advanced successional stages in the region (Peng and Wang, 1995). The PF (approximately $22 \mathrm{ha}$ ), originally planted by local people in the 1950s, was dominated by Pinus massoniana in the tree layer and Baeckea frutescens, Rhodomyrtus tomentosa, and Dicranopteris linearis in the shrub and herb layers. The MF (approximately $557 \mathrm{ha}$ ) was developed from artificial pine forest with a gradual invasion of some pioneer broadleaf species through natural succession. The upper canopy of the community is dominated by Schima superba, Castanopsis chinensis, and Craibiodendron scleranthum var. kwangtungense. Artificial disturbances have not occurred in the MF for about $100 \mathrm{yr}$. The BF (approximately $218 \mathrm{ha}$ ) located in the central area of the reserve was dominated by Castanopsis chinensis, Cryptocarya concinna, Schima superba, and Machilus chinensis without any Pinus massoniana. No disturbance was recorded for the past $400 \mathrm{yr}$ in the BF (Wang and Ma, 1982; Shen et al., 2001). Stand characteristics of the three forest sites have been reported in Deng et al. (2012).

\subsection{Experimental design}

We used a two-factor experimental design considering forest ecosystem type and precipitation treatment. At each forest site, a randomized block design was used with three blocks. In each block, three precipitation treatments were randomly arranged. From November 2006, precipitation in the precipitation exclusion (EP) plots was intercepted using transparent polyvinyl chloride (PVC) sheer roof (Borken et al., 2006) and was redistributed to the double precipitation (DP) plots using pipes similar to those used in Zhou et al. (2006). The control that received ambient precipitation (AP) was built next to these treatment plots in each forest site. Each plot was $3 \times 3 \mathrm{~m}^{2}$, and the distance between plots was more than $1 \mathrm{~m}$. In order to minimize the washing effect of double rainfall, the pipes in the DP plots were close to soil surface and the distance between the pipes and the soil surface is only $5 \mathrm{~cm}$. Around each EP plot, the thick PVC panels were inserted at the top $15 \mathrm{~cm}$ soil layer to prevent surface runoff and lateral movement of water from the outside surrounding soil. As precipitation interception roofs prevented litterfall in the EP plots, we collected litterfall from nearby plots with the same area and evenly distributed to the EP plots after each measurement of soil respiration. 
Table 1. Review of soil respiration models with soil temperature and moisture.

\begin{tabular}{|c|c|}
\hline Functions & References \\
\hline \multicolumn{2}{|l|}{ Section 1: Temperature functions } \\
\hline$R=R_{0} e^{b T}$ & $\begin{array}{l}\text { Van’t Hoff (1884); } \\
\text { Lloyd and Taylor (1994) }\end{array}$ \\
\hline$R=a e^{E / r T}$ & Arrhenius (1898) \\
\hline$R=R_{10} e^{(E / 283.15 r T)(1-283.15 / T)}$ & Lloyd and Taylor (1994) \\
\hline$R=a+b T$ & Rochette et al. (1991) \\
\hline$R=R_{0} e^{\left(b T+c T^{2}\right)}$ & O'Connell (1990) \\
\hline$R=a(T+10)^{b}$ & Kucera and Kirkham (1971) \\
\hline$R=R_{10}+a(T+10)^{2}$ & Holthausen and Caldwell (1980) \\
\hline$R=1 /\left(a+b^{-((T-10) / 10)}\right)$ & Jenkinson (1990) \\
\hline \multicolumn{2}{|l|}{ Section 2: Moisture functions } \\
\hline$R=a+c M$ & Tang et al. (2006) \\
\hline$R=a M^{2}+c M+d$ & Doran et al. (1991) \\
\hline$R=a\left(M-M_{\min }\right)\left(M_{\max }-M\right)^{c}$ & Mielnick and Dugas (2000) \\
\hline$R=-a \ln (-\psi)+c$ & $\begin{array}{l}\text { Orchard and Cook (1983); } \\
\text { Davidson et al. (2000) }\end{array}$ \\
\hline$R=\exp \left(-e^{a-c M}\right)$ & Janssens et al. (2001) \\
\hline$R=a(W-d) /(c+W-d)$ & Liu et al. (2002) \\
\hline \multicolumn{2}{|c|}{ Section 3: Combined functions including both temperature and moisture } \\
\hline$R=a c^{M} e^{b T}$ & Gulledge and Schimel (2000) \\
\hline$R=a e^{b T}-(M-c)^{2}$ & Gullege and Schimel (2000) \\
\hline$R=a e^{b T} M /(M+c)$ & Gullege and Schimel (2000) \\
\hline$R=\left(a e^{c M}\right) e^{b(T-10)}$ & Lavigne et al. (2004) \\
\hline$R=a \pm b W T$ & Wildung et al. (1975) \\
\hline$R=a e^{b T}\left(M-M_{\min }\right)\left(M_{\max }-M\right)^{c}$ & Mielnick and Dugas (2000) \\
\hline$R=a M^{c} T^{b}$ & Qi et al. (2002) \\
\hline$R=(W /(a+W))(b /(b+W)) c d^{(T+10) / 10}$ & $\begin{array}{l}\text { Bunnel et al. (1977); } \\
\text { Schlentner and Van Cleve (1985) }\end{array}$ \\
\hline$R=f(M) f(T)$ & Reichstein et al. (2002) \\
\hline$R=(a M+c) e^{b T}$ & Reichstein et al. (2002) \\
\hline$R=\left(a M^{2}+c M+d\right) e^{b T}$ & Reichstein et al. (2002) \\
\hline
\end{tabular}

$R$ is soil respiration ( $\mu \mathrm{mol} \mathrm{CO} \mathrm{m}^{-2} \mathrm{~s}^{-1}$ ); $R_{0}$ and $R_{10}$ are basal soil respiration when $T=0$ and $10^{\circ} \mathrm{C}$, respectively; $T$ is soil temperature $\left({ }^{\circ} \mathrm{C}\right) ; M$ is volumetric soil moisture (\% vol.); $W$ is gravimetric soil moisture $\left(\mathrm{g} \mathrm{kg}^{-1}\right) ; \psi$ is soil water potential; $f(M)$ and $f(T)$ are the functions of soil respiration with temperature and moisture, respectively; $E$ is defined as the activation energy $\left(\mathrm{kJ} \mathrm{mol}^{-1}\right) ; r$ is universal gas constant $\left(8.314 \mathrm{~J} \mathrm{~mol}^{-1} \mathrm{~K}^{-1}\right)$; $\mathrm{a}, \mathrm{b}, \mathrm{c}$ and $\mathrm{d}$ are the functional coefficients.

\subsection{Soil respiration, temperature and moisture measurements}

Five PVC soil collars $\left(80 \mathrm{~cm}^{2}\right.$ in area and $5 \mathrm{~cm}$ in height) were permanently installed $3 \mathrm{~cm}$ into the soil in each plot in November 2006. The distance between adjacent collars was more than $50 \mathrm{~cm}$. Soil respiration was measured three times a month in 2007 using a Li-6400 infrared gas analyzer (Li-COR, Inc., Lincoln, Nebraska, USA) connected to a $\mathrm{Li}-6400-09$ soil respiration chamber $(9.55 \mathrm{~cm}$ diameter) (Li-COR, Inc., Lincoln, Nebraska, USA). The measurements were made between 9.00 a.m. and 12.00 a.m. local time. Previous work at the DNR forests has demonstrated that soil res- piration measured during this period was close to daily mean (Tang et al., 2006). In order to ensure the measuring stability of the instrument, soil respiration was measured three times for each soil collar. Once the soil respiration values in the three time measurements vary greatly and no obvious disturbance was found, we would calibrate the instrument and measure again. Soil respiration in a collar was calculated as the mean of three time measurements. Soil respiration in a treatment plot was calculated as the mean of five collar measurements (the measurement at five collars in a plot mostly differed by less than $5 \%$ at any measurement period). Soil temperature at $5 \mathrm{~cm}$ below the soil surface was also monitored with a thermocouple sensor attached to the 
respiration chamber during the soil respiration measurement. Volumetric soil moisture of the top $5 \mathrm{~cm}$ soil layer was measured on five random locations within a treatment plot using a PMKit (ICT, Australia; see http://www.ictinternational. com.au/soils.htm), which consists of three amplitude domain reflectometry (ADR) moisture probes (MP406) and a data logger (MPM160 meter).

\subsection{Modeling soil respiration with soil temperature and moisture}

Previous work at the DNR forests demonstrated that soil respiration increases exponentially with soil temperature and linearly with soil moisture (Tang et al., 2006; Deng et al., 2010, 2012). In this study, we focused on the seasonal responses of soil respiration to altered precipitation in the three subtropical forest sites, and fitted soil respiration $(R)$ to both soil temperature $(T)$ and moisture $(M)$ for each season. To develop the best regression model of soil respiration with soil temperature and moisture in the three subtropical forest sites, we conducted a thorough review of soil respiration models and fitted these univariate and bivariate models (Table 1). We evaluated these models using the coefficient of determination $\left(R^{2}\right)$ and bias in the distribution of the residues. The results indicated that either

$R=\left(a_{1}+c_{1} M\right) \exp \left(b_{1} T\right)$

or

$R=\left(a_{2}+c_{2} M+d_{2} M^{2}\right) \exp \left(b_{2} T\right)$

was the best regression model (Table A4). Thus, we fitted all data using these two regression equations. Model parameter $b_{1}$ and $b_{2}$ are related to temperature sensitivity, and the $Q_{10}$ value can be estimated as $Q_{10}=\exp \left(10 b_{1}\right)$ or $\exp \left(10 b_{2}\right)$. For soil moisture sensitivity, the parameter $c_{1}$ can be considered as soil moisture sensitivity in Eq. (1), as it reflects a relative change in soil respiration due to one unit change of soil moisture. In Eq. (2), we first estimated optimum soil moisture as $M_{\mathrm{o}}=-b_{2} / 2 a_{2}$. Similar to the $Q_{10}$ value, we defined two soil moisture sensitivities as $M_{10,1}=f\left(M_{\mathrm{o}}+10, T\right) / f\left(M, T_{0}\right)$ and/or $M_{10,2}=f\left(M, T_{0}\right) / f\left(M-10, T_{0}\right)$, where $T_{0}$ is average soil temperature.

We further used $t$ test to determine the difference of the functional coefficients, as well as soil temperature and moisture sensitivity between seasons and among forest sites and precipitation treatments.

\subsection{Soil microbial biomass and fine root biomass measurements}

To determine soil microbial biomass carbon, soil samples $(0-20 \mathrm{~cm}$ depth) were collected in February, May, August and November of 2007. Each time, two samples of six cores $(2.5 \mathrm{~cm}$ diameter) were randomly collected from each plot in the three forest sites. After removing roots and plant residues, the composite samples were immediately sieved through a $2 \mathrm{~mm}$ mesh sieve. The soil microbial biomass carbon was calculated using the fumigation-extraction method (Vance et al., 1987).

To measure fine root biomass (diameter $\leq 3 \mathrm{~mm}$ ), we also randomly collected soil corns $(0-20 \mathrm{~cm}$ depth) in February 2007 using a $10 \mathrm{~cm}$ diameter stainless-steel corer, and three more times in April, August and October of 2007. Each time, two samples were randomly collected from each plot in the three forest sites. The fine roots were separated by washing and sieving, dried at $60^{\circ} \mathrm{C}$ for $48 \mathrm{~h}$ and weighed.

\subsection{Statistical analysis}

Soil respiration and soil temperature in a plot were calculated as the means of five collar measurements. Soil moisture was calculated as the mean of five measurements at random locations in a plot. We used the repeated measure analysis of variance (ANOVA) to test the differences in soil respiration rate, soil temperature and soil moisture among forest sites, precipitation treatments, and seasons. Tukey's multiple comparison test (HSD, honestly significant difference) was conducted if significant effects of forest ecosystem types, precipitation treatments or seasons were found. Similar ANOVAs were also used to test the differences in fine root and soil microbial biomass among forest sites, precipitation treatments, and seasons. Tukey's multiple comparison test (HSD) was conducted if significant effects of forest ecosystem types, precipitation treatments or seasons were found. For soil respiration models, linear and nonlinear regression methods were applied. All data analyses were carried out using the SAS software version 9.1 (SAS Institute Inc., Cary, NC, USA).

\section{Results}

\subsection{Soil temperature and soil moisture}

Among the three forest sites, soil in the PF was significantly warmer than those in the other two forest sites $(p<0.05)$. No significant difference in soil temperature was found between MF and BF $(p>0.05)$. In all the three forest sites, soil temperature in the dry season was significantly lower than those in the wet season $(p<0.05)$ (Fig. 1). The mean values of soil temperature in the wet season were 24.7, 23.2 and $23.2^{\circ} \mathrm{C}$ for the $\mathrm{PF}, \mathrm{MF}$ and $\mathrm{BF}$, respectively. Mean soil temperatures in the dry season were $18.7,16.4$ and $16.3^{\circ} \mathrm{C}$ for the PF, MF and BF, respectively. Precipitation treatments did not significantly change soil temperature in all three forest sites (Tables 2 and 3).

Among the three forest sites, soil in the PF was significantly dryer than those in the MF and $\mathrm{BF}(p<0.05)$. No significant difference in annual mean soil moisture was found between MF and $\mathrm{BF}(p>0.05)$. Soil moisture under the AP treatment also displayed a strong seasonal variation 


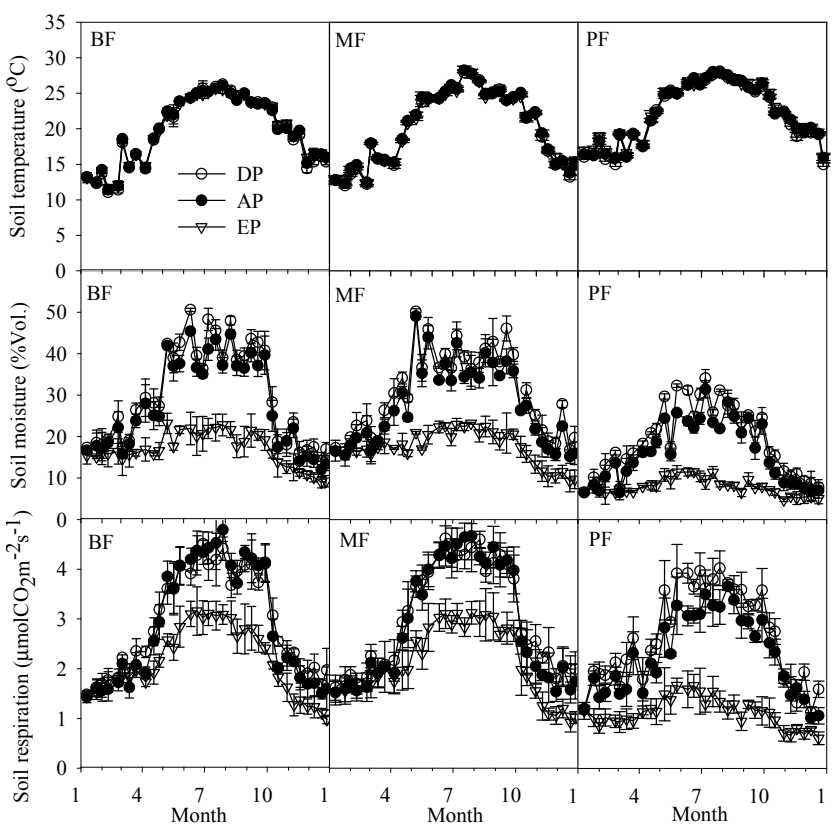

Fig. 1. Seasonal dynamics of soil temperature at $5 \mathrm{~cm}$ depth, soil moisture of the top $5 \mathrm{~cm}$ soil layer, and soil respiration rate under different precipitation treatments at the DNR forests. The treatments are as follows: precipitation exclusion (EP), AP ambient precipitation (AP), and double precipitation (DP). The forests are as follows: broadleaf forest (BF), mixed forest (MF), and pine forest (PF). Error bars are standard deviations.

in all three forest sites $(p<0.05)$ (Fig. 1). The mean values of soil moisture in the wet season were $22.0 \%$ vol. for PF, $35.4 \%$ vol. for MF and $36.0 \%$ vol. for BF, respectively. The mean values of soil moisture in the dry season were $9.4 \%$ vol. for PF, $19.0 \%$ vol. for MF and $17.8 \%$ vol. for BF, respectively. Soil moisture was significantly influenced by precipitation treatments (Table 2). Compared to the controls, soil moisture decreased under the EP treatments by about $58.6 \%$ for $\mathrm{PF}, 43.2 \%$ for $\mathrm{MF}$ and $44.4 \%$ for $\mathrm{BF}$, respectively, in the wet season, and about $34.0 \%$ for PF, $25.7 \%$ for $\mathrm{MF}$ and $23.8 \%$ for BF, respectively, in the dry season (Table 3). The soil moisture increased under the DP treatment by approximately $3 \%$ vol. in all three forest sites, compared to the controls (Table 3 ).

\subsection{Soil respiration}

Among the three forest sites, soil respiration was significantly greater in the BF and MF than those in the PF $(p<$ 0.05 ). There were no significant differences of soil respiration between the $\mathrm{BF}$ and the MF $(p>0.05)$. In all three forest sites, soil respiration in the wet season was significantly higher than those in the dry season $(p<0.05)$ (Fig. 1). In the controls, mean soil respiration in the wet season was 2.79, 3.85 and $3.89 \mu \mathrm{mol} \mathrm{CO} \mathrm{m}^{-2} \mathrm{~s}^{-1}$ in the PF, MF and
Table 2. Significance of the effects of forest type, precipitation treatment, season and their interactions on soil respiration rate, soil temperature, and soil moisture, respectively, at the Dinghushan Nature Reserve, China. Numbers are $F$ values. Stars indicate the level of significance $\left(^{*}=P<0.05,{ }^{* *}=P<0.01\right)$.

\begin{tabular}{llll}
\hline Source & $\begin{array}{l}\text { Soil } \\
\text { respiration }\end{array}$ & $\begin{array}{l}\text { Soil } \\
\text { temperature }\end{array}$ & $\begin{array}{l}\text { Soil } \\
\text { moisture }\end{array}$ \\
\hline Forest & $90.39^{* *}$ & $45.99^{* *}$ & $584.99^{* *}$ \\
Treatment & $204.28^{* *}$ & 0.15 & $663.33^{* *}$ \\
Forest $\times$ Treatment & $6.39^{* *}$ & 0.13 & 2.10 \\
Season & $972.46^{* *}$ & $1173.16^{* *}$ & $1907.69^{* *}$ \\
Forest $\times$ Season & $23.76^{* *}$ & $3.64^{*}$ & $21.64^{* *}$ \\
Treatment $\times$ Season & $35.17^{* *}$ & 0.76 & $168.19^{* *}$ \\
Forest $\times$ Treatment & 0.87 & 0.12 & 0.32 \\
$\quad \times$ Season & & & \\
\hline
\end{tabular}

$\mathrm{BF}$, respectively, and in the dry season was $1.62,1.82$ and $1.83 \mu \mathrm{mol} \mathrm{CO}_{2} \mathrm{~m}^{-2} \mathrm{~s}^{-1}$ in the PF, MF and BF, respectively.

Soil respiration was influenced significantly by precipitation treatments, and varied among the three forest sites and seasons (Table 2). In the BF and MF, annual mean soil respiration was not significantly different between the DP and AP plots (Table 3). Only in the PF, soil respiration increased by $18.0 \%$ under the DP treatment (Table 3). The EP treatment decreased the soil respiration significantly in all three forest sites (Table 3). Annual mean soil respiration rates under the EP treatment decreased by $25.9 \%, 27.2 \%$, and $50.9 \%$ in the $\mathrm{BF}, \mathrm{MF}$, and PF, respectively (Table 3). Soil respiration in the dry season increased significantly with increasing precipitation treatments in all three forest sites (Fig. 2). In the wet season, soil respiration was decreased by the EP treatment in all three forest sites (Fig. 2). However, the DP treatment increased soil respiration by $19.2 \%$ in the PF only (Fig. 2).

\subsection{Relationships of soil respiration with soil temperature and moisture}

Similar to previous work at the DNR forest sites, soil respiration $(R)$ was significantly related to soil temperature $(T)$ with an exponential function, and to soil moisture $(M)$ with a linear regression model (Tables A1 and A2; Figs. A1 and A2). However, some residuals in the linear function with soil moisture exhibited non-linear behavior, especially in the wet season (Fig. A4). Thus, we also developed non-linear regressions of soil respiration with soil moisture. Among all tested soil moisture models (Table 1), the moisture function describing the quadratic distribution was selected (Table A3). Compared to the linear function, the quadratic function slightly improved model fitting and its residual distribution (Fig. A5).

Since soil temperature and moisture interactively regulated soil respiration in these sites, we further fitted soil respiration $(R)$ with soil temperature $(T)$ and soil moisture $(M)$ 
Table 3. Mean annual values of soil temperature at $5 \mathrm{~cm}$ depth, soil moisture of the top $5 \mathrm{~cm}$ soil layer, soil respiration rate, fine root biomass and soil microbial biomass under ambient precipitation (AP), precipitation exclusion (EP) and double precipitation (DP) treatments from the broadleaf forest $(\mathrm{BF})$, the mixed forest $(\mathrm{MF})$ and the pine forest $(\mathrm{PF})$ (mean \pm standard error). Mean values in each forest site within a row with a different superscripted letter have significant treatment differences at $\alpha=0.05$ level.

\begin{tabular}{|c|c|c|c|c|c|c|c|c|c|}
\hline \multirow{2}{*}{ Variable } & \multicolumn{3}{|c|}{ Broadleaf forest (BF) } & \multicolumn{3}{|c|}{ Mixed forest (MF) } & \multicolumn{3}{|c|}{ Pine forest $(\mathrm{PF})$} \\
\hline & EP & $\mathrm{AP}$ & DP & EP & AP & DP & EP & $\mathrm{AP}$ & DP \\
\hline Soil temperature & $19.92^{\mathrm{a}}$ & $19.87^{\mathrm{a}}$ & $19.77^{\mathrm{a}}$ & $19.76^{\mathrm{a}}$ & $19.82^{\mathrm{a}}$ & $19.66^{\mathrm{a}}$ & $22.02^{\mathrm{a}}$ & $21.85^{\mathrm{a}}$ & $21.69^{\mathrm{a}}$ \\
\hline$\left({ }^{\circ} \mathrm{C}\right)$ & \pm 0.77 & \pm 0.78 & \pm 0.82 & \pm 0.82 & \pm 0.83 & \pm 0.85 & \pm 0.65 & \pm 0.67 & \pm 0.69 \\
\hline Soil moisture & $16.91^{\mathrm{a}}$ & $27.05^{\mathrm{b}}$ & $29.36^{c}$ & $17.21^{\mathrm{a}}$ & $27.45^{\mathrm{b}}$ & $30.24^{c}$ & $7.75^{\mathrm{a}}$ & $16.02^{\mathrm{b}}$ & $18.82^{\mathrm{c}}$ \\
\hline (\% vol.) & \pm 0.69 & \pm 1.79 & \pm 1.93 & \pm 0.68 & \pm 1.62 & \pm 1.67 & \pm 0.33 & \pm 1.24 & \pm 1.41 \\
\hline Soil respiration & $2.14^{\mathrm{a}}$ & $2.89^{\mathrm{b}}$ & $2.95^{\mathrm{b}}$ & $2.08^{\mathrm{a}}$ & $2.86^{\mathrm{b}}$ & $2.97^{\mathrm{b}}$ & $1.10^{\mathrm{a}}$ & $2.24^{\mathrm{b}}$ & $2.64^{\mathrm{c}}$ \\
\hline$\left(\mu \mathrm{mol} \mathrm{CO} \mathrm{C}^{-2} \mathrm{~s}^{-1}\right)$ & \pm 0.12 & \pm 0.20 & \pm 0.17 & \pm 0.12 & \pm 0.20 & \pm 0.17 & \pm 0.05 & \pm 0.13 & \pm 0.16 \\
\hline Fine root biomass & $99.52^{\mathrm{a}}$ & $139.23^{\mathrm{b}}$ & $138.31^{\mathrm{b}}$ & $94.89^{\mathrm{a}}$ & $131.83^{\mathrm{b}}$ & $131.90^{\mathrm{b}}$ & $66.42^{\mathrm{a}}$ & $101.21^{\mathrm{b}}$ & $124.90^{\mathrm{c}}$ \\
\hline$\left(\mathrm{g} \mathrm{m}^{-2}\right)$ & \pm 8.69 & \pm 4.92 & \pm 4.82 & \pm 9.27 & \pm 5.73 & \pm 4.41 & \pm 5.22 & \pm 5.00 & \pm 4.47 \\
\hline Soil microbial biomass & $448.32^{\mathrm{a}}$ & $558.57^{\mathrm{b}}$ & $594.78^{\mathrm{b}}$ & $218.40^{\mathrm{a}}$ & $371.37^{b}$ & $402.71^{b}$ & $194.40^{\mathrm{a}}$ & $293.33^{b}$ & $355.41^{\mathrm{c}}$ \\
\hline ( $\mathrm{g} \mathrm{kg}^{-1}$ soil) & \pm 21.39 & \pm 24.83 & \pm 31.78 & \pm 19.58 & \pm 21.12 & \pm 19.60 & \pm 16.99 & \pm 22.70 & \pm 19.16 \\
\hline
\end{tabular}
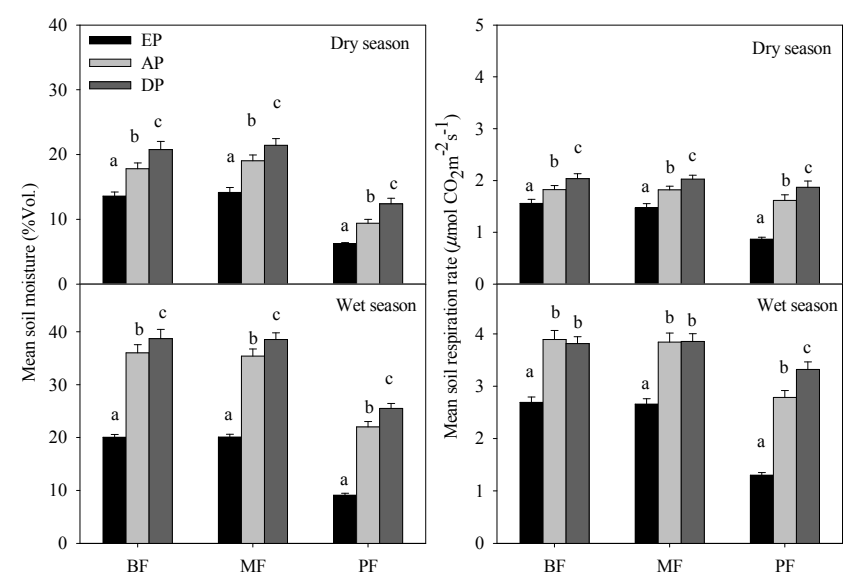

Fig. 2. Mean values of soil moisture and soil respiration rate under different seasons and different precipitation treatments at the DNR forests. The treatments are as follows: precipitation exclusion (EP), ambient precipitation (AP), and double precipitation (DP). The forests are as follows: broadleaf forest (BF), mixed forest (MF), and pine forest $(\mathrm{PF})$. Error bars are standard errors.

together. We tested different models in Table 1 and found that a combined exponential and linear function or a combined exponential and quadratic function was the best regression model (Reichstein et al., 2002; Deng et al., 2012; Table A4). Including soil temperature and moisture into the soil respiration model significantly improved model fittings including higher coefficient of determination $\left(R^{2}\right)$ and reduced bias in the distribution of the residue (Tables 4 and 5; Figs. A6 and A7).

In both Eqs. (1) and (2), there were no significant differences of soil temperature sensitivity in the control among the three forest sites in the dry season (Tables 4 and 5). In the wet season, soil temperature sensitivity was significantly greater in the $\mathrm{BF}$ and MF than those in the PF (Tables 4 and 5). Soil moisture sensitivity in both dry and wet season was significantly greater in the PF than those in the BF and MF (Table 4; Fig. 3). There was no significant difference of soil moisture sensitivity between the BF and the MF (Table 4; Fig. 3). Soil moisture sensitivities in the wet season were significantly lower than those in the dry season in all three forest sites (Table 4; Fig. 3), but the soil temperature sensitivities showed an opposite trend (Tables 4 and 5).

For precipitation treatments, the EP treatment significantly reduced temperature sensitivities of soil respiration, and increased soil moisture sensitivities in both the wet season and dry season in all three forest sites (Table 4; Fig. 3). The DP treatment in the wet season significantly decreased the temperature sensitivities in the BF and MF (Tables 4 and 5). In the dry season, there was no significant difference of temperature and moisture sensitivity of soil respiration between the DP and AP treatments in all three forest sites (Tables 4 and 5; Fig. 3).

\subsection{Soil microbial biomass and fine root biomass}

Among the three forest sites, fine root biomass was significantly greater in the $\mathrm{BF}$ and MF than those in the PF (Table 3). There were no significant differences of soil respiration between the $\mathrm{BF}$ and MF ( $p>0.05)$. In all three forest sites, the fine root biomass was higher in the wet season than those in the dry season (Fig. 4). Only in the PF, however, the season difference of the fine root biomass was significant $(p<0.05)$. The soil microbial biomass was greatest in the $\mathrm{BF}$, compared to that in the MF and PF (Table 3). In all three forest sites, soil microbial biomass was significantly higher in the wet season than those in the dry season $(p<0.05)$ (Fig. 4). 


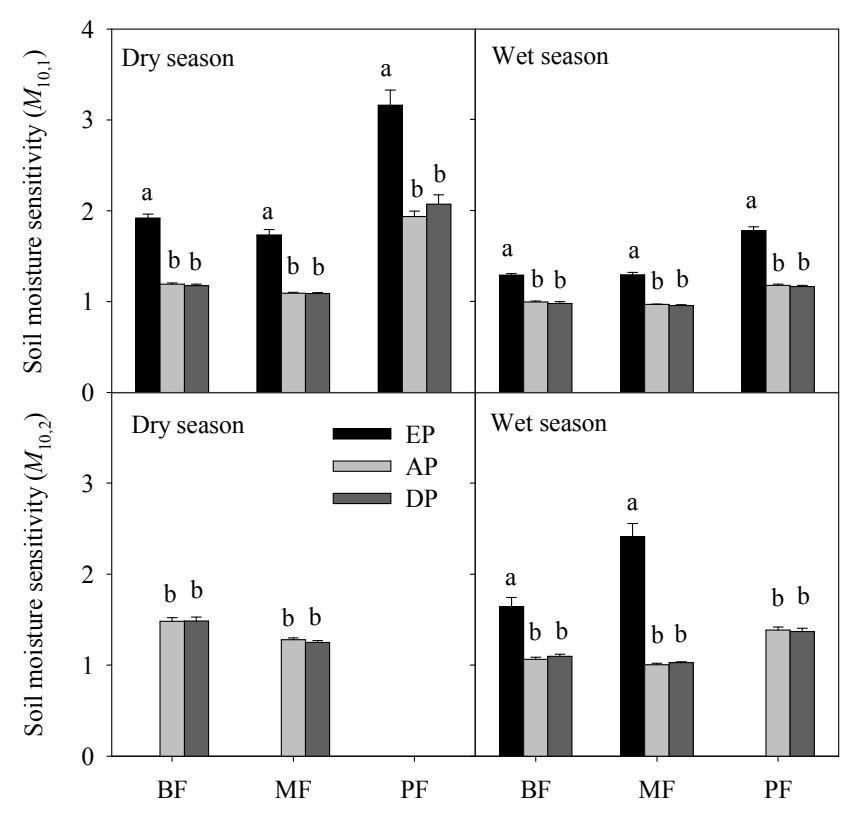

Fig. 3. Moisture sensitivities of soil respiration $\left(M_{10,1}\right.$ and $\left.M_{10,2}\right)$ in Eq. (2) under different seasons and different precipitation treatments at the DNR forests. The treatments are as follows: precipitation exclusion (EP), ambient precipitation (AP), and double precipitation (DP). The forests are as follows: broadleaf forest (BF), mixed forest $(\mathrm{MF})$, and pine forest $(\mathrm{PF})$. Error bars are standard errors. Eq. (2) and its coefficients are listed in Table 5. Several $M_{10,2}$ values were not calculated because some of soil moisture in the plots is less than $10 \%$ vol.

Both soil microbial biomass and fine root biomass were significantly influenced by precipitation treatments, and varied among the three forest sites and seasons (Table 3). In the wet season, the DP treatment increased fine root biomass and soil microbial biomass by $16.5 \%$ and $20.9 \%$, respectively, in the PF (Fig. 4). The EP treatment decreased fine root biomass and soil microbial biomass in all three forest sites (Fig. 4; Table 3). In the dry season, both fine root biomass and soil microbial biomass showed significant increasing trend with increasing precipitation treatments in the three forest sites (Fig. 4).

\section{Discussion}

\subsection{Effects of precipitation treatments on soil respiration}

In the past three decades, seasonal precipitation pattern and intensity in the region have varied drastically, and soil moisture in forest sites has decreased significantly (Zhou et al., 2011). Many precipitation manipulation experiments have indicated that soil respiration often increased following water additions and decreased following precipitation exclusion (Harper et al., 2005; Borken et al., 2006; Zhou et al., 2006;
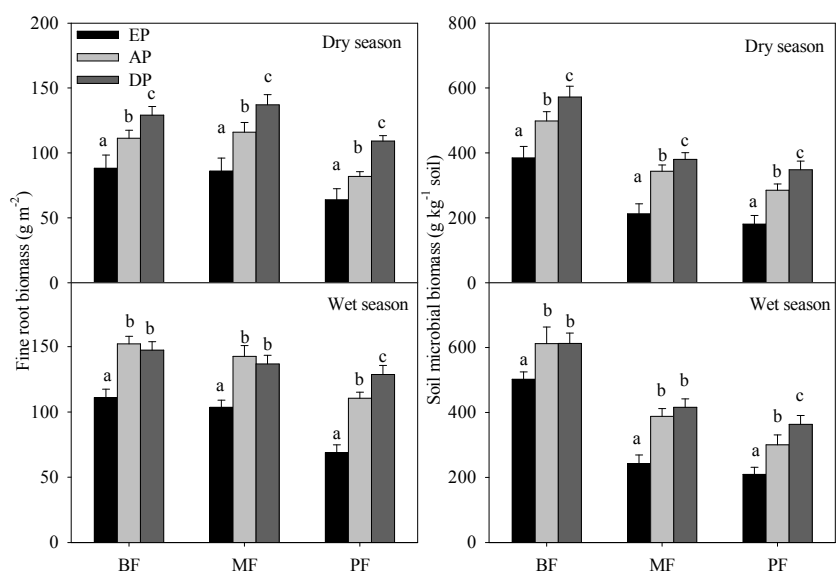

Fig. 4. Mean values of fine root biomass and soil microbial biomass under different seasons and different precipitation treatments at the DNR forests. The treatments are as follows: precipitation exclusion (EP), ambient precipitation (AP), and double precipitation (DP). The forests are as follows: broadleaf forest (BF), mixed forest (MF), and pine forest $(\mathrm{PF})$. Error bars are standard errors.

Liu et al., 2009). Precipitation can influence soil respiration mainly by altering soil moisture, in turn influencing root respiration and soil microbial decomposition (Davidson et al., 2000; Joffre et al., 20003; Williams, 2007). Our results also showed soil respiration was responsive to altered precipitation through the effect of soil moisture on plant and microbial activities. In this study, the EP treatment decreased soil respiration significantly throughout the year in all three forest sites (Table 3; Fig. 2), accompanied by decreases in fine root and soil microbial biomass (Fig. 4). For the DP treatment, the responses of soil respiration varied between seasons and differed among the three forest sites. The DP treatment in the $\mathrm{BF}$ and MF increased soil respiration in the dry season only (Fig. 2). Even in the wet season, however, soil respiration in the PF showed a significant influence by the DP treatment (Fig. 2). Similar result was also reported in other studies (Talmon et al., 2011). In temperate grasslands, soil respiration responded to water addition at drier sites only (Risch and Frank, 2007). In Mediterranean-type ecosystems, responses of soil respiration to precipitation manipulations varied with seasons and years, depending on respective precipitation amounts (Asencio et al., 2007; Chou et al., 2008). Results from a humid tropical forest indicated that soil respiration may be decreased under precipitation increase (Cleveland et al., 2010).

Different responses to the DP treatment between seasons and among the three forest sites might be attributed to differences in water status, soil condition and vegetation at these study sites. Being favored by the subtropical monsoon, subtropical forests in southern China often received an abundance of precipitation resources, of which nearly $80 \%$ fall in the wet season (April-September) (Ding et al., 2001). Therefore, soil moisture in these forests experiences a strong 
Table 4. Relationships of soil respiration $\left(R, \mu \mathrm{mol} \mathrm{CO} \mathrm{m}^{-2} \mathrm{~s}^{-1}\right)$ with soil temperature $\left(T,{ }^{\circ} \mathrm{C}\right)$ and soil moisture $(M$, \% vol.) using a combined exponential and linear function $\left(R=\left(a_{1}+c_{1} M\right) \exp \left(b_{1} T\right)\right.$, where $a_{1}$ is parameter related to basal soil respiration when both $T=0$ and $M=0 ; b_{1}$ and $c_{1}$ are parameters related to the temperature and moisture sensitivities of soil respiration, respectively) under different seasons and precipitation treatments at the DNR forests (parameter estimate \pm standard error). The treatments are as follows: precipitation exclusion (EP), ambient precipitation (AP), and double precipitation (DP). The forests are as follows: broadleaf forest (BF), mixed forest $(\mathrm{MF})$, and pine forest (PF). $R^{2}$ is the coefficient of determination. Numbers in bold indicate the level of function fitting is significant $(p<0.05)$. Different superscripted letters in each forest site within a column denote significant difference $(p<0.05)$ among precipitation treatments.

\begin{tabular}{|c|c|c|c|c|c|}
\hline Forests & Treatments & $a_{1}$ & $b_{1}$ & $c_{1}$ & $R^{2}$ \\
\hline \multicolumn{6}{|c|}{ Wet season } \\
\hline \multirow[t]{3}{*}{$\mathrm{BF}$} & EP & $0.4723 \pm 0.1094$ & $0.0421 \pm 0.0066^{\mathrm{a}}$ & $0.0268 \pm 0.0106^{\mathrm{a}}$ & 0.93 \\
\hline & AP & $0.6572 \pm 0.0842$ & $0.0720 \pm 0.0056^{\mathrm{b}}$ & $0.0017 \pm 0.0015^{\mathrm{b}}$ & 0.95 \\
\hline & DP & $1.1751 \pm 0.1515$ & $0.0535 \pm 0.0058^{\mathrm{a}}$ & $-0.0023 \pm 0.0021^{b}$ & 0.89 \\
\hline \multirow[t]{3}{*}{ MF } & $\mathrm{EP}$ & $0.4654 \pm 0.0952$ & $0.0446 \pm 0.0067^{\mathrm{a}}$ & $0.0234 \pm 0.0099^{\mathrm{a}}$ & 0.95 \\
\hline & AP & $0.6164 \pm 0.0587$ & $0.0735 \pm 0.0038^{\mathrm{b}}$ & $0.0020 \pm 0.0011^{\mathrm{b}}$ & 0.98 \\
\hline & DP & $1.0254 \pm 0.1427$ & $0.0577 \pm 0.0054^{\mathrm{a}}$ & $-0.0008 \pm 0.0030^{b}$ & 0.92 \\
\hline \multirow[t]{3}{*}{ PF } & EP & $0.1366 \pm 0.0734$ & $0.0039 \pm 0.0049^{\mathrm{a}}$ & $0.1146 \pm 0.0181^{\mathrm{a}}$ & 0.94 \\
\hline & AP & $0.3894 \pm 0.0957$ & $0.0502 \pm 0.0109^{\mathrm{b}}$ & $0.0184 \pm 0.0081^{\mathrm{b}}$ & 0.89 \\
\hline & DP & $0.5085 \pm 0.1000$ & $0.0583 \pm 0.0087^{\mathrm{b}}$ & $0.0105 \pm 0.0044^{\mathrm{b}}$ & 0.91 \\
\hline \multicolumn{6}{|c|}{ Dry season } \\
\hline \multirow[t]{3}{*}{$\mathrm{BF}$} & $\mathrm{EP}$ & $-0.0262 \pm 0.1219$ & $0.0217 \pm 0.0056^{\mathrm{a}}$ & $0.0820 \pm 0.0106^{\mathrm{a}}$ & 0.86 \\
\hline & AP & $0.5738 \pm 0.0602$ & $0.0385 \pm 0.0038^{\mathrm{b}}$ & $0.0219 \pm 0.0039^{\mathrm{b}}$ & 0.93 \\
\hline & DP & $0.6766 \pm 0.0878$ & $0.0393 \pm 0.0050^{\mathrm{b}}$ & $0.0200 \pm 0.0055^{\mathrm{b}}$ & 0.89 \\
\hline \multirow[t]{3}{*}{ MF } & $\mathrm{EP}$ & $-0.0598 \pm 0.0460$ & $0.0163 \pm 0.0025^{\mathrm{a}}$ & $0.0837 \pm 0.0045^{\mathrm{a}}$ & 0.98 \\
\hline & AP & $0.6102 \pm 0.1319$ & $0.0338 \pm 0.0070^{\mathrm{b}}$ & $0.0206 \pm 0.0084^{\mathrm{b}}$ & 0.87 \\
\hline & DP & $0.9674 \pm 0.0498$ & $0.0388 \pm 0.0028^{\mathrm{b}}$ & $0.0051 \pm 0.0025^{\mathrm{b}}$ & 0.95 \\
\hline \multirow[t]{3}{*}{$\mathrm{PF}$} & $\mathrm{EP}$ & $-0.0075 \pm 0.0204$ & $-0.0054 \pm 0.0115^{\mathrm{a}}$ & $0.1435 \pm 0.0184^{\mathrm{a}}$ & 0.56 \\
\hline & AP & $0.0682 \pm 0.1236$ & $0.0315 \pm 0.0119^{b}$ & $0.0820 \pm 0.0204^{b}$ & 0.81 \\
\hline & DP & $0.2084 \pm 0.1628$ & $0.0292 \pm 0.0129^{b}$ & $0.0772 \pm 0.0154^{\mathrm{b}}$ & 0.75 \\
\hline
\end{tabular}

seasonality (Figs. 1 and 2). In particular, soils moisture in the BF and MF was relatively high in the wet season, so that root respiration and microbial decomposition may not be subject to water limitation. In these two forest sites, indeed, we found that the fine root and soil microbial biomass under the DP treatment increased significantly in the dry season, but not in the wet season (Fig. 4). As a result, the DP treatment in the BF and MF did not increase soil respiration in the wet season. Soil in the PF contains more sand, less clay, and more gravel, and had lower ambient moisture content than those in the BF and MF. Trees in the PF were younger and smaller in biomass and leaf area index (LAI) (Zhang et al., 2006). Therefore, unlike the other two forest sites, fine root and soil microbial biomass in the PF were low, and even in the wet season were responsive to precipitation increase. Accordingly, soil respiration under the DP treatment increased significantly throughout the year.

\subsection{Effects of precipitation treatments on soil temperature and moisture sensitivities}

The magnitude of soil respiration feedback to climate change depends largely on model function, in particular soil temperature and moisture sensitivities related to carbon supply (Kirschbaum, 2010; Suseela et al., 2012). For example, in this study, the DP treatment increased soil respiration in the PF only (Table 3), which was attributed to its higher soil moisture sensitivity than those in the BF and MF (Table 4; Fig. 3). Similarly, the DP treatment increased soil respiration of the MF and BF in the dry season only, associated with their higher soil moisture sensitivity in the dry season (Table 4; Fig. 3).

Shifts of plant and microbial activities under the precipitation treatments altered soil respiration, and might also modify soil temperature/moisture sensitivity (Zogg et al., 1997; Luo et al., 2001; Zhang et al., 2005; Noormets et al., 2008; Deng et al., 2012). Our results on both combined functions confirmed that precipitation changes can influence soil temperature sensitivity of soil respiration ( $b_{1}$ and $b_{2}$ values). Soil temperature sensitivity was reduced significantly by the EP 
Table 5. Relationships of soil respiration $\left(\mu \mathrm{mol} \mathrm{CO}_{2} \mathrm{~m}^{-2} \mathrm{~s}^{-1}\right)$ with soil temperature $\left({ }^{\circ} \mathrm{C}\right)$ and soil moisture $(\%$ vol.) using a combined exponential and quadratic function $\left(R=\left(a_{2} M^{2}+c_{2} M+d_{2}\right) \exp \left(b_{2} T\right)\right.$, where $R$ is soil respiration, $T$ is soil temperature, $M$ soil moisture, and $a_{2}, b_{2}, c_{2}$ and $d_{2}$ the functional coefficients; especially the $b_{2}$ value can be directly considered as the parameter related to the temperature sensitivity of soil respiration) under different seasons and precipitation treatments at the DNR forests (parameter estimate \pm standard error). The treatments are as follows: precipitation exclusion (EP), ambient precipitation (AP), and double precipitation (DP). The forests are as follows: broadleaf forest $(\mathrm{BF})$, mixed forest $(\mathrm{MF})$, and pine forest $(\mathrm{PF}) . R^{2}$ is the coefficient of determination. Numbers in bold indicate the level of function fitting is significant $(p<0.05)$. Different superscripted letters in each forest site within a column denote significant difference $(p<0.05)$ among precipitation treatments.

\begin{tabular}{lllllll}
\hline Forests & Treatments & $a_{2}$ & $b_{2}$ & $c_{2}$ & $d_{2}$ & $R^{2}$ \\
\hline \multicolumn{2}{l}{ Wet season } & & & & & \\
\hline BF & EP & $-0.0009 \pm 0.0034$ & $0.0456 \pm 0.0081^{\mathrm{a}}$ & $0.0778 \pm 0.1399$ & $-0.0438 \pm 1.3076$ & $\mathbf{0 . 9 3}$ \\
& AP & $-0.0002 \pm 0.0002$ & $0.0744 \pm 0.0066^{\mathrm{b}}$ & $0.0159 \pm 0.0176$ & $0.3011 \pm 0.2817$ & $\mathbf{0 . 9 6}$ \\
& DP & $-0.0007 \pm 0.0003$ & $0.0504 \pm 0.0052^{\mathrm{a}}$ & $0.0581 \pm 0.0249$ & $0.2100 \pm 0.4241$ & $\mathbf{0 . 9 2}$ \\
MF & EP & $-0.0023 \pm 0.0022$ & $0.0431 \pm 0.0064^{\mathrm{a}}$ & $0.1540 \pm 0.0903$ & $-0.7866 \pm 0.8558$ & $\mathbf{0 . 9 6}$ \\
& AP & $-0.0001 \pm 0.0002$ & $0.0712 \pm 0.0051^{\mathrm{b}}$ & $0.0063 \pm 0.0163$ & $0.4512 \pm 0.2445$ & $\mathbf{0 . 9 8}$ \\
& DP & $-0.0004 \pm 0.0006$ & $0.0540 \pm 0.0055^{\mathrm{a}}$ & $0.0303 \pm 0.0507$ & $0.4403 \pm 0.8703$ & $\mathbf{0 . 9 3}$ \\
PF & EP & $-0.0026 \pm 0.0062$ & $0.0040 \pm 0.0051^{\mathrm{a}}$ & $0.1617 \pm 0.1170$ & $-0.0779 \pm 0.5269$ & $\mathbf{0 . 9 4}$ \\
& AP & $-0.0004 \pm 0.0008$ & $0.0484 \pm 0.0118^{\mathrm{b}}$ & $0.0355 \pm 0.0387$ & $0.2409 \pm 0.3594$ & $\mathbf{0 . 9 0}$ \\
& DP & $-0.0005 \pm 0.0006$ & $0.0553 \pm 0.0093^{\mathrm{b}}$ & $0.0463 \pm 0.0345$ & $0.1706 \pm 0.3663$ & $\mathbf{0 . 9 1}$ \\
\hline Dry season & & & & & \\
\hline BF & EP & $0.0034 \pm 0.0053$ & $0.0234 \pm 0.0062^{\mathrm{a}}$ & $-0.0625 \pm 0.1412$ & $0.8828 \pm 0.8797$ & $\mathbf{0 . 8 8}$ \\
& AP & $-0.0006 \pm 0.0009$ & $0.0396 \pm 0.0044^{\mathrm{b}}$ & $0.0451 \pm 0.0352$ & $0.3498 \pm 0.3425$ & $\mathbf{0 . 9 3}$ \\
& DP & $-0.0008 \pm 0.0012$ & $0.0396 \pm 0.0053^{\mathrm{b}}$ & $0.0588 \pm 0.0504$ & $0.2750 \pm 0.5445$ & $\mathbf{0 . 9 1}$ \\
MF & EP & $-0.0008 \pm 0.0018$ & $0.0165 \pm 0.0046^{\mathrm{a}}$ & $0.1067 \pm 0.0050$ & $-0.2215 \pm 0.3259$ & $\mathbf{0 . 9 8}$ \\
& AP & $-0.0006 \pm 0.0015$ & $0.0379 \pm 0.0052^{\mathrm{b}}$ & $0.0377 \pm 0.0628$ & $0.4906 \pm 0.6512$ & $\mathbf{0 . 8 7}$ \\
& DP & $-0.0007 \pm 0.0005$ & $0.0387 \pm 0.0038^{\mathrm{b}}$ & $0.0481 \pm 0.0242$ & $0.6037 \pm 0.2676$ & $\mathbf{0 . 9 6}$ \\
PF & EP & $-0.0108 \pm 0.0285$ & $-0.0002 \pm 0.0110^{\mathrm{a}}$ & $0.6881 \pm 0.4770$ & $-1.6414 \pm 1.4094$ & $\mathbf{0 . 6 7}$ \\
& AP & $-0.0009 \pm 0.0067$ & $0.0364 \pm 0.0133^{\mathrm{b}}$ & $0.1037 \pm 0.1368$ & $0.0158 \pm 0.6583$ & $\mathbf{0 . 8 2}$ \\
& DP & $0.0099 \pm 0.0077$ & $0.0335 \pm 0.0126^{\mathrm{b}}$ & $-0.1565 \pm 0.1753$ & $1.6093 \pm 1.0399$ & $\mathbf{0 . 7 5}$ \\
\hline
\end{tabular}

treatment in all three forest sites (Tables 4 and 5). One of the reasons for the lower temperature sensitivity was that drought reduces contact among the substrate, the extracellular enzymes and the microbes involved in decomposition (Jassal et al., 2008). The EP treatment significantly reduced soil microbial biomass in all three forest sites (Fig. 4; Table 2). Another reason was that drought could reduce substrate supply (Davidson et al., 2006) by a decrease in photosynthesis (Harper et al., 2005; Jassal et al., 2008), which decreases translocation of recent photosynthates to the rhizosphere (Högberg et al., 2001; Bhupinderpal-Singh et al., 2003). Significant decreases of fine root biomass were also revealed in our EP plots across all three forest sites (Fig. 4; Table 3).

We also found that the DP treatments in the BF and MF reduced temperature sensitivities in the wet season (Tables 4 and 5). This might be related to the decreases in soil aeration and soil oxygen concentration due to high soil moisture (Cleveland et al., 2010). Due to the subtropical monsoon climate, forests at the DNR receive an abundance of heat, light, and water resources in the wet season (Ding et al., 2001). Soil respiration response to temperature in these moist forests is often limited by soil oxygen concentration and substrate during the wet season (Schwendenmann and Veldkamp, 2005; Yan et al., 2009; Deng et al., 2011). In the PF where soil moisture was still low even in the wet season, enhanced soil moisture due to the DP treatment might have no effect on soil aeration and soil oxygen concentration, and hence did not change soil temperature sensitivity. Moreover, enhanced fine root biomass under the DP treatment may increase substrate supply (Högberg et al., 2001; BhupinderpalSingh et al., 2003), stimulate microbial activity (Fig. 4), and in turn offset the negative effect of the DP treatment on soil temperature sensitivity in the PF. It will be useful for further studies to evaluate effects of precipitation on plant productivity associated with soil respiration functional change. Similar to many previous studies (Boddy, 1983; Orchard and Cook, 1983; Davidson and Janssens, 2006), using a precipitation manipulation field experiment we found that temperature sensitivity of soil respiration peaked at intermediate soil water content, and declined under both wetter and drier conditions.

The moisture sensitivities of soil respiration were also significantly influenced by precipitation treatments, and showed 
rising trends with precipitation decrease in the three forest sites (Table 4; Fig. 3). Similarly, many studies have shown that, when soil moisture was within a site-specific threshold, soil temperature is typically a reliable predictor of soil respiration. In the presence of a drought, however, soil respiration is more sensitive to soil moisture (e.g., Moncrieff and Fang, 1999; Xu and Qi, 2001; Curiel Yuste et al., 2003; Davidson et al., 2006). The response mechanism of soil moisture sensitivity to precipitation change is still unclear. Two biological processes may help explain the shift in soil moisture sensitivity in this study. First, fungi can tolerate greater water stress than can bacteria due to their filamentous nature (Holland and Coleman, 1987). Previous research has reported high fungal activity under drier and warmer soils, while high bacteria activity under moister and colder soils (Zhang et al., 2005; Yuste et al., 2011). Shifts in soil microbial community structure could effect the water requirement for litter and soil organic matter decomposition, and alter moisture sensitivity of soil respiration. Second, root growth response to drought may compensate by enhancing water use efficiency and capturing water in deep soil under high water conditions (Espeleta and Clark, 2007; Lima et al., 2010).

The findings of shifts in soil temperature and moisture sensitivities could have potential implications for climatecarbon modeling, as uncertainty remains regarding environmental controls over soil respiration. While much controversy surrounds the effect of warming on the temperature sensitivity of soil respiration (e.g., Luo et al., 2001; Conant et al., 2008; Reth et al., 2009), our results highlighted the relative importance of precipitation and seasonal variation in determining the responses of soil respiration to not only soil temperature, but also to soil moisture. Lower temperature sensitivity indicated that soil respiration would have limited response to climate warming. High moisture sensitivity under drought conditions indicated that soil respiration would decrease more strongly if soil moisture continues to reduce. Ecosystem modeling that does not include this change in soil temperature and moisture sensitivities with precipitation or seasonal variations may produce misleading conclusions (Heimann and Reichstein, 2008; Medvigy et al., 2010; Falloon et al., 2011).

\subsection{Limitation of the study}

In this study, we selected three typical forest ecosystems in the south of China and tested the effects of precipitation alteration on soil respiration. One shortcoming of the experimental design was the plot size used. We decided the plot size based on the common practices in manipulation experiments, availability of adequate plots for building precipitation interception and redistribution facility, and heterogeneity of plots. While the $3 \mathrm{~m} \times 3 \mathrm{~m}$ plots were employed for drought treatments (EP), it is difficult to detect the whole ecosystem responses - mainly deep root respiration. Thus, the inferences regarding to the response of autotrophic respiration to drought should be read with caution. Further studies are needed to draw rigorous conclusions regarding forest ecosystem responses using larger plots.

\section{Conclusions}

Using a precipitation manipulation field experiment, we found that soil respiration in subtropical forests was responsive to precipitation, but the response pattern was nonlinear depending on either seasons or forest types. Precipitation alteration could modify both temperature and moisture sensitivities of soil respiration. Considering variation of precipitation intensity and seasonal pattern in subtropical China (Zhou et al., 2011), the contrasting seasonal responses of soil respiration to precipitation and the shifts of moisture or temperature sensitivities of soil respiration may have large impacts on subtropical forest ecosystem carbon cycling and feedback to climate change. Our results indicated that soil respiration would decrease in the subtropical forests if soil moisture continues to decrease in the future. More rainfall in the wet season could have limited effect on the response of soil respiration to climate warming. 
Table A1. Relationships of soil respiration rate $\left(R, \mu \mathrm{mol} \mathrm{CO} \mathrm{m}^{-2} \mathrm{~s}^{-1}\right)$ and soil temperature at $5 \mathrm{~cm}$ depth $\left(T\right.$, $\left.{ }^{\circ} \mathrm{C}\right)$ using an exponential equation $\left(R=R_{0} \exp (b T)\right.$, where parameter $R_{0}$ is basal soil respiration when $T=0$, and $b_{0}$ is related to soil temperature sensitivity $\left(Q_{10}=\right.$ $\exp \left(10 b_{0}\right)$ ) (parameter estimate \pm standard error) under different seasons and precipitation treatments at the DNR forests. The treatments are as follows: precipitation exclusion (EP), ambient precipitation (AP), and double precipitation (DP). The forests are as follows: broadleaf forest $(\mathrm{BF})$, mixed forest $(\mathrm{MF})$, and pine forest $(\mathrm{PF}) . R^{2}$ is the coefficient of determination. Numbers in bold indicate the level of function fitting is significant $(p<0.05)$. Different superscripted letters in each forest site within a column denote significant difference $(p<0.05)$ among precipitation treatments.

\begin{tabular}{|c|c|c|c|c|}
\hline Forests & Treatments & $R_{0}$ & $b$ & $R^{2}$ \\
\hline \multicolumn{5}{|c|}{ Wet season } \\
\hline \multirow[t]{3}{*}{$\mathrm{BF}$} & $\mathrm{EP}$ & $0.6837 \pm 0.1056$ & $0.0586 \pm 0.0064^{\mathrm{a}}$ & 0.87 \\
\hline & $\mathrm{AP}$ & $0.6769 \pm 0.0858$ & $0.0746 \pm 0.0053^{\mathrm{b}}$ & 0.95 \\
\hline & DP & $1.1487 \pm 0.1505$ & $0.0511 \pm 0.0054^{\mathrm{a}}$ & 0.88 \\
\hline \multirow[t]{3}{*}{ MF } & $\mathrm{EP}$ & $0.6199 \pm 0.0831$ & $0.0624 \pm 0.0056^{\mathrm{a}}$ & 0.91 \\
\hline & AP & $0.6564 \pm 0.0612$ & $0.0754 \pm 0.0039^{b}$ & 0.97 \\
\hline & DP & $1.0053 \pm 0.1214$ & $0.0572 \pm 0.0050^{\mathrm{a}}$ & 0.92 \\
\hline \multirow[t]{3}{*}{ PF } & $\mathrm{EP}$ & $0.8042 \pm 0.3401$ & $0.0194 \pm 0.0169^{a}$ & 0.08 \\
\hline & $\mathrm{AP}$ & $0.4190 \pm 0.1448$ & $0.0761 \pm 0.0136^{\mathrm{b}}$ & 0.73 \\
\hline & DP & $0.5188 \pm 0.1358$ & $0.0747 \pm 0.0103^{\mathrm{b}}$ & 0.82 \\
\hline \multicolumn{5}{|c|}{ Dry season } \\
\hline \multirow[t]{3}{*}{$\mathrm{BF}$} & EP & $1.3226 \pm 0.3562$ & $0.0099 \pm 0.0148^{\mathrm{a}}$ & 0.02 \\
\hline & AP & $0.8427 \pm 0.1134$ & $0.0466 \pm 0.0077^{b}$ & 0.70 \\
\hline & DP & $0.9193 \pm 0.1141$ & $0.0487 \pm 0.0071^{\mathrm{b}}$ & 0.75 \\
\hline \multirow[t]{3}{*}{ MF } & $\mathrm{EP}$ & $1.3687 \pm 0.4183$ & $0.0044 \pm 0.0181^{\mathrm{a}}$ & 0.01 \\
\hline & $\mathrm{AP}$ & $0.9274 \pm 0.1178$ & $0.0407 \pm 0.0073^{b}$ & 0.67 \\
\hline & DP & $1.0236 \pm 0.0474$ & $0.0420 \pm 0.0076^{\mathrm{b}}$ & 0.74 \\
\hline \multirow[t]{3}{*}{ PF } & $\mathrm{EP}$ & $1.2596 \pm 0.4563$ & $-0.0226 \pm 0.0193^{\mathrm{a}}$ & 0.08 \\
\hline & $\mathrm{AP}$ & $0.6577 \pm 0.3624$ & $0.0473 \pm 0.0284^{\mathrm{b}}$ & 0.14 \\
\hline & DP & $0.7624 \pm 0.3799$ & $0.0484 \pm 0.0260^{\mathrm{b}}$ & 0.17 \\
\hline
\end{tabular}
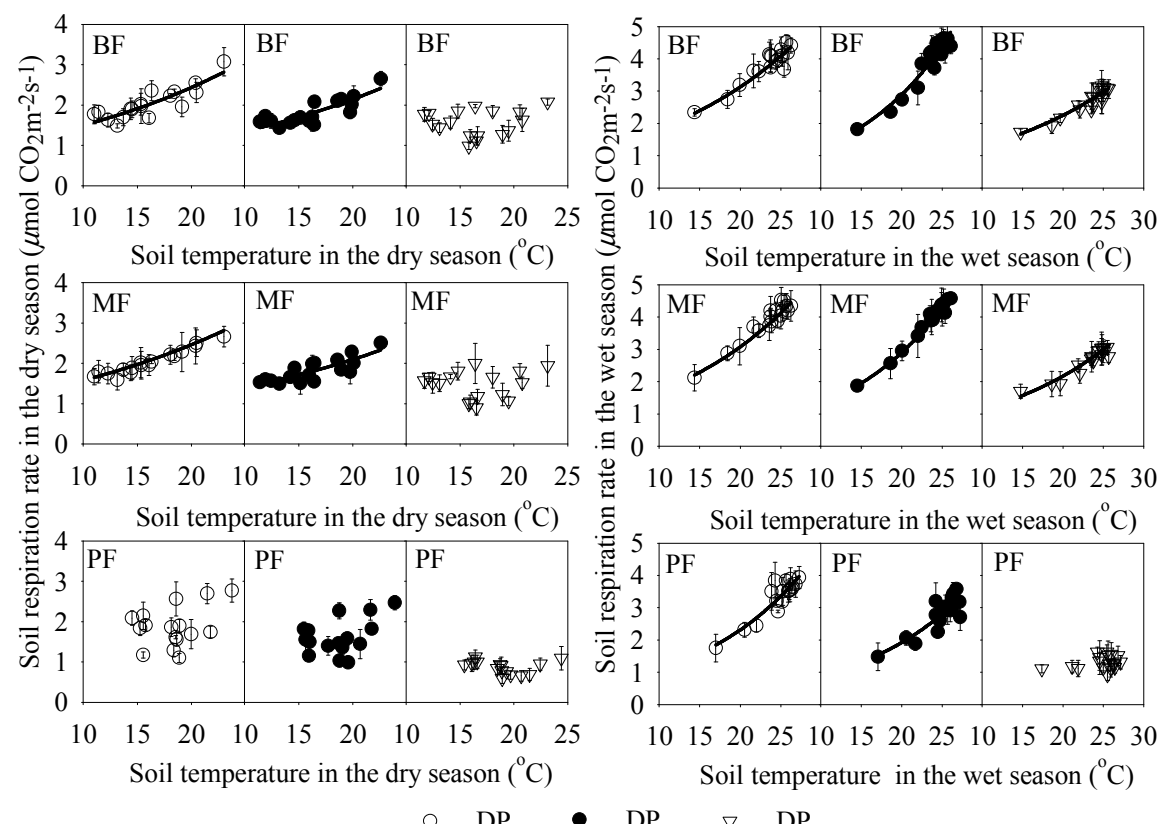

Fig. A1. Relationships of soil respiration rate $\left(R, \mu \mathrm{mol} \mathrm{CO} \mathrm{Cm}^{-2} \mathrm{~s}^{-1}\right)$ and soil temperature at $5 \mathrm{~cm}$ depth $\left(T\right.$, $\left.{ }^{\circ} \mathrm{C}\right)($ exponential equation: $R=$ $R_{0} \exp (b T)$ ) under different seasons and different precipitation treatments at the DNR forests. The treatments are as follows: precipitation exclusion (EP), ambient precipitation (AP), and double precipitation (DP). The forests are as follows: broadleaf forest (BF), mixed forest (MF), and pine forest (PF). The equations are listed in Table A1. 
Table A2. Relationships of soil respiration $\left(R, \mu \mathrm{mol} \mathrm{CO} \mathrm{m}^{-2} \mathrm{~s}^{-1}\right)$ and soil moisture of the top $5 \mathrm{~cm}$ soil layer (M, \% vol.) using a linear regression equation ( $R=a+c M$, where parameter $a$ is intercept, basal soil respiration when $M=0$; and $c$ is slope of regression representing the soil moisture sensitivity of soil respiration) (parameter estimate \pm standard error) under different seasons and precipitation treatments at the DNR forests. The treatments are as follows: precipitation exclusion (EP), ambient precipitation (AP), and double precipitation (DP). The forests are as follows: broadleaf forest (BF), mixed forest (MF), and pine forest (PF). $R^{2}$ is the coefficient of determination. Numbers in bold indicate the level of function fitting is significant $(p<0.05)$. Different superscripted letters in each forest site within a column denote significant difference $(p<0.05)$ among precipitation treatments.

\begin{tabular}{lllll}
\hline Forests & Treatments & $a$ & $c$ & $R^{2}$ \\
\hline \multicolumn{2}{l}{ Wet season } & & & \\
\hline BF & EP & $-0.6482 \pm 0.2479$ & $0.1682 \pm 0.0248^{\mathrm{a}}$ & $\mathbf{0 . 7 4}$ \\
& AP & $1.4607 \pm 0.8362$ & $0.0675 \pm 0.0229^{\mathrm{b}}$ & 0.30 \\
& DP & $2.5073 \pm 0.6997$ & $0.0335 \pm 0.0177^{\mathrm{b}}$ & 0.18 \\
MF & EP & $-0.8731 \pm 0.4567$ & $0.1758 \pm 0.0226^{\mathrm{a}}$ & $\mathbf{0 . 7 9}$ \\
& AP & $1.4781 \pm 0.9550$ & $0.0669 \pm 0.0267^{\mathrm{b}}$ & 0.28 \\
& DP & $1.9409 \pm 1.0366$ & $0.0498 \pm 0.0266^{\mathrm{b}}$ & 0.18 \\
PF & EP & $0.1316 \pm 0.0799$ & $0.1284 \pm 0.0087^{\mathrm{a}}$ & $\mathbf{0 . 9 3}$ \\
& AP & $0.3426 \pm 0.3924$ & $0.1110 \pm 0.0175^{\mathrm{a}}$ & $\mathbf{0 . 7 2}$ \\
& DP & $0.8289 \pm 0.5157$ & $0.0977 \pm 0.0199^{\mathrm{a}}$ & $\mathbf{0 . 6 0}$ \\
\hline \multirow{2}{*}{ Dry season } & & & \\
\hline \multirow{2}{*}{ BF } & EP & $0.1226 \pm 0.2360$ & $0.1056 \pm 0.0171^{\mathrm{a}}$ & $\mathbf{0 . 7 2}$ \\
& AP & $0.8289 \pm 0.3192$ & $0.0559 \pm 0.0176^{\mathrm{b}}$ & $\mathbf{0 . 4 0}$ \\
\multicolumn{6}{l}{ MF } & DP & $0.8056 \pm 0.3928$ & $0.0624 \pm 0.0195^{\mathrm{b}}$ & $\mathbf{0 . 4 1}$ \\
& EP & $-0.0131 \pm 0.1226$ & $0.1049 \pm 0.0085^{\mathrm{a}}$ & $\mathbf{0 . 9 1}$ \\
& AP & $0.6237 \pm 0.2462$ & $0.0628 \pm 0.0127^{\mathrm{b}}$ & $\mathbf{0 . 6 2}$ \\
PF & DP & $1.1528 \pm 0.3307$ & $0.0408 \pm 0.0151^{\mathrm{b}}$ & $\mathbf{0 . 5 3}$ \\
& EP & $-0.0082 \pm 0.1827$ & $0.1410 \pm 0.0292^{\mathrm{a}}$ & $\mathbf{0 . 6 3}$ \\
& AP & $0.3358 \pm 0.2893$ & $0.1361 \pm 0.0298^{\mathrm{a}}$ & $\mathbf{0 . 6 0}$ \\
& DP & $0.4234 \pm 0.3040$ & $0.1267 \pm 0.0258^{\mathrm{a}}$ & $\mathbf{0 . 5 5}$ \\
\hline
\end{tabular}
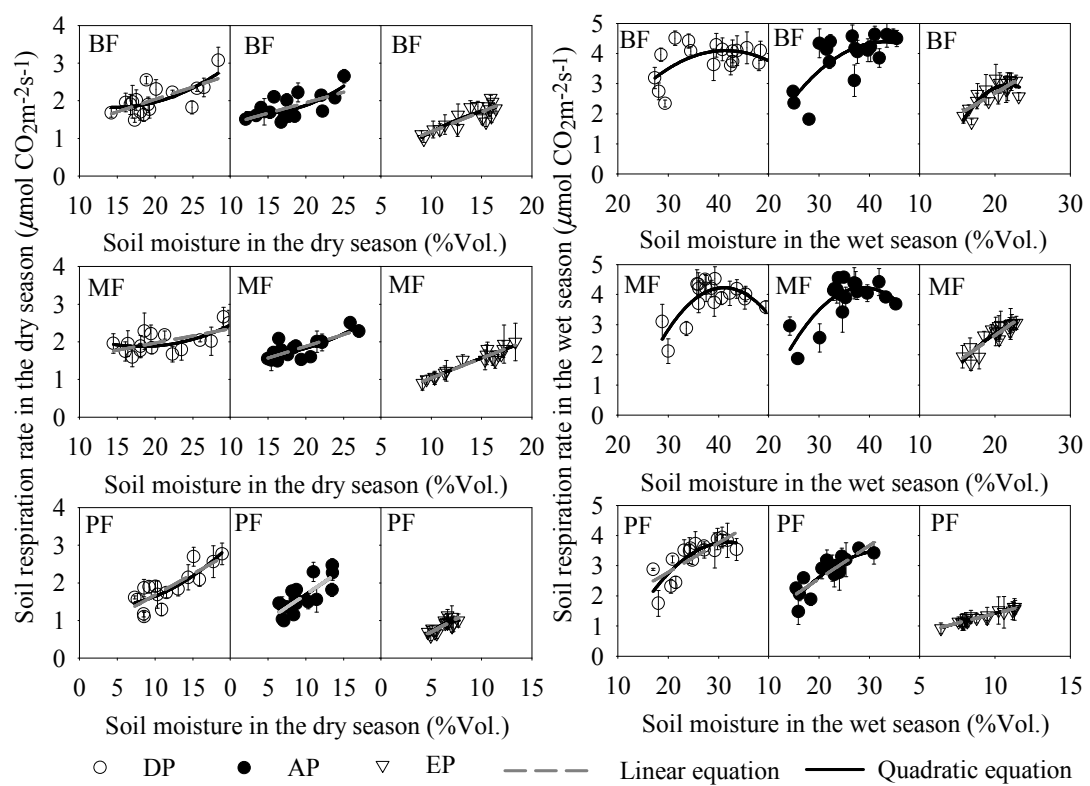

Fig. A2. Relationships of soil respiration rate $\left(R, \mu \mathrm{mol} \mathrm{CO} \mathrm{m}^{-2} \mathrm{~s}^{-1}\right)$ and soil moisture of the top $5 \mathrm{~cm}$ soil layer $(M$, \% vol.) (linear regression equation: $R=a+c M$ and quadratic equation: $\left.R=a_{0} M^{2}+c_{0} M+d_{0}\right)$ under different seasons and different precipitation treatments at the DNR forests. The treatments are as follows: precipitation exclusion (EP), ambient precipitation (AP), and double precipitation (DP). The forests are as follows: broadleaf forest (BF), mixed forest (MF), and pine forest (PF). The equations are listed in Tables A2 and A3. 
Table A3. Relationships of soil respiration $\left(\mu \mathrm{mol} \mathrm{CO} \mathrm{m}^{-2} \mathrm{~s}^{-1}\right)$ and soil moisture of the top $5 \mathrm{~cm}$ soil layer (\% vol.) using a quadratic function ( $R=a_{0} M^{2}+c_{0} M+d_{0}$, where $R$ is soil respiration, $M$ soil moisture, and $a_{0}, c_{0}$ and $d_{0}$ are constants) (parameter estimate \pm standard error) under different seasons and precipitation treatments at the DNR forests. The treatments are as follows: precipitation exclusion (EP), ambient precipitation (AP), and double precipitation (DP). The forests are as follows: broadleaf forest (BF), mixed forest (MF), and pine forest (PF). $R^{2}$ is the coefficient of determination. Numbers in bold indicate the level of function fitting is significant $(p<0.05)$. Different superscripted letters in each forest site within a column denote significant difference $(p<0.05)$ among precipitation treatments.

\begin{tabular}{llllll}
\hline \multirow{2}{*}{ Forests } & Treatments & $a_{0}$ & \multicolumn{2}{l}{$c_{0}$} & $d_{0}$ \\
\hline \multicolumn{2}{l}{ Wet season } & & & & $R^{2}$ \\
BF & EP & $-0.0335 \pm 0.133$ & $1.4545 \pm 0.5220$ & $-12.8359 \pm 5.0507$ & $\mathbf{0 . 7 3}$ \\
& AP & $-0.0057 \pm 0.0037$ & $0.4940 \pm 0.2627$ & $-6.2303 \pm 4.5180$ & $\mathbf{0 . 5 6}$ \\
& DP & $-0.0046 \pm 0.0026$ & $0.3838 \pm 0.1987$ & $-3.8462 \pm 3.6920$ & $\mathbf{0 . 4 1}$ \\
MF & EP & $-0.0119 \pm 0.0113$ & $0.6389 \pm 0.4415$ & $-5.3160 \pm 4.2549$ & $\mathbf{0 . 8 1}$ \\
& AP & $-0.0099 \pm 0.0030$ & $0.7630 \pm 0.2071$ & $-10.5340 \pm 3.5847$ & $\mathbf{0 . 6 2}$ \\
& DP & $-0.0115 \pm 1.0029$ & $0.9407 \pm 0.2222$ & $-15.0781 \pm 4.2909$ & $\mathbf{0 . 6 1}$ \\
PF & EP & $-0.0025 \pm 0.0068$ & $0.1755 \pm 0.1268$ & $-0.0808 \pm 0.5771$ & $\mathbf{0 . 9 3}$ \\
& AP & $-0.0047 \pm 0.0033$ & $0.3176 \pm 0.1489$ & $-1.8666 \pm 1.6276$ & $\mathbf{0 . 7 5}$ \\
& DP & $-0.0074 \pm 0.0039$ & $0.4733 \pm 0.1996$ & $-3.7559 \pm 2.4725$ & $\mathbf{0 . 6 9}$ \\
\hline \multirow{2}{*}{ Dry season } & & & & \\
\hline \multirow{2}{*}{ BF } & EP & $-0.0058 \pm 0.0098$ & $0.2555 \pm 0.2526$ & $-0.8030 \pm 1.5742$ & $\mathbf{0 . 7 3}$ \\
& AP & $0.0060 \pm 0.0045$ & $-0.1677 \pm 0.1673$ & $2.8331 \pm 1.5236$ & $\mathbf{0 . 4 7}$ \\
& DP & $0.0050 \pm 0.0052$ & $-0.1411 \pm 0.2244$ & $2.9170 \pm 2.3434$ & $\mathbf{0 . 4 9}$ \\
MF & EP & $-0.0010 \pm 0.0044$ & $0.1313 \pm 0.1199$ & $-0.1828 \pm 0.7794$ & $\mathbf{0 . 9 1}$ \\
& AP & $0.0036 \pm 0.0036$ & $-0.0863 \pm 0.1464$ & $2.0990 \pm 1.4633$ & $\mathbf{0 . 6 5}$ \\
& DP & $0.0041 \pm 0.0027$ & $-0.1506 \pm 0.1244$ & $3.2451 \pm 1.3643$ & $\mathbf{0 . 5 1}$ \\
PF & EP & $-0.0446 \pm 0.0359$ & $0.6856 \pm 0.4398$ & $-1.6358 \pm 1.3237$ & $\mathbf{0 . 6 7}$ \\
& AP & $0.0010 \pm 0.0163$ & $0.1168 \pm 0.3311$ & $0.4277 \pm 1.5955$ & $\mathbf{0 . 6 0}$ \\
& DP & $0.0059 \pm 0.0068$ & $-0.0380 \pm 0.1750$ & $1.4326 \pm 1.0481$ & $\mathbf{0 . 7 0}$ \\
\hline
\end{tabular}
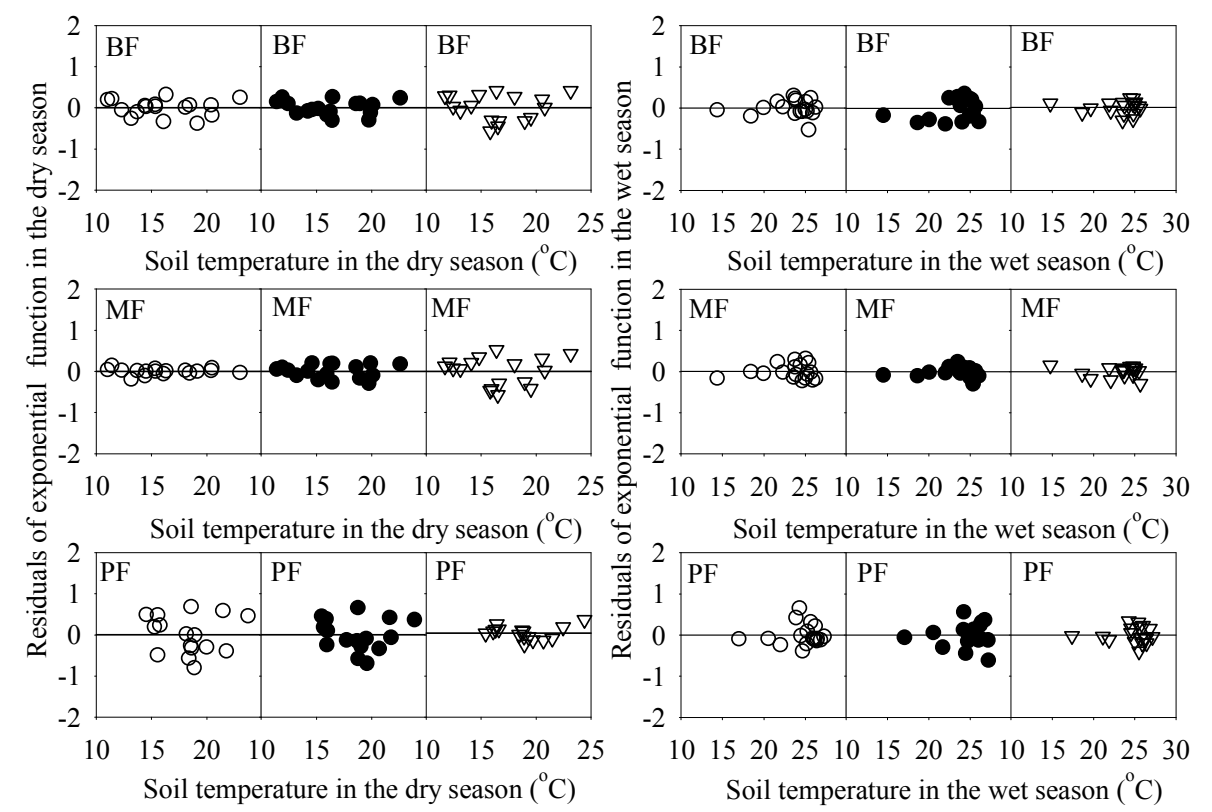

$$
\circ \quad \mathrm{DP} \quad \bullet \quad \mathrm{DP} \quad \nabla \quad \mathrm{DP}
$$

Fig. A3. Residual plots for the models of soil respiration rate $\left(R, \mu \mathrm{mol} \mathrm{CO} \mathrm{m}^{-2} \mathrm{~s}^{-1}\right)$ and soil temperature at $5 \mathrm{~cm} \mathrm{depth}\left(T,{ }^{\circ} \mathrm{C}\right)(\operatorname{exponential}$ equation: $\left.R=R_{0} \exp \left(b_{0} T\right)\right)$ under different seasons and different precipitation treatments at the DNR forests. The treatments are as follows: precipitation exclusion (EP), ambient precipitation (AP), and double precipitation (DP). The forests are as follows: broadleaf forest (BF), mixed forest (MF), and pine forest (PF). 

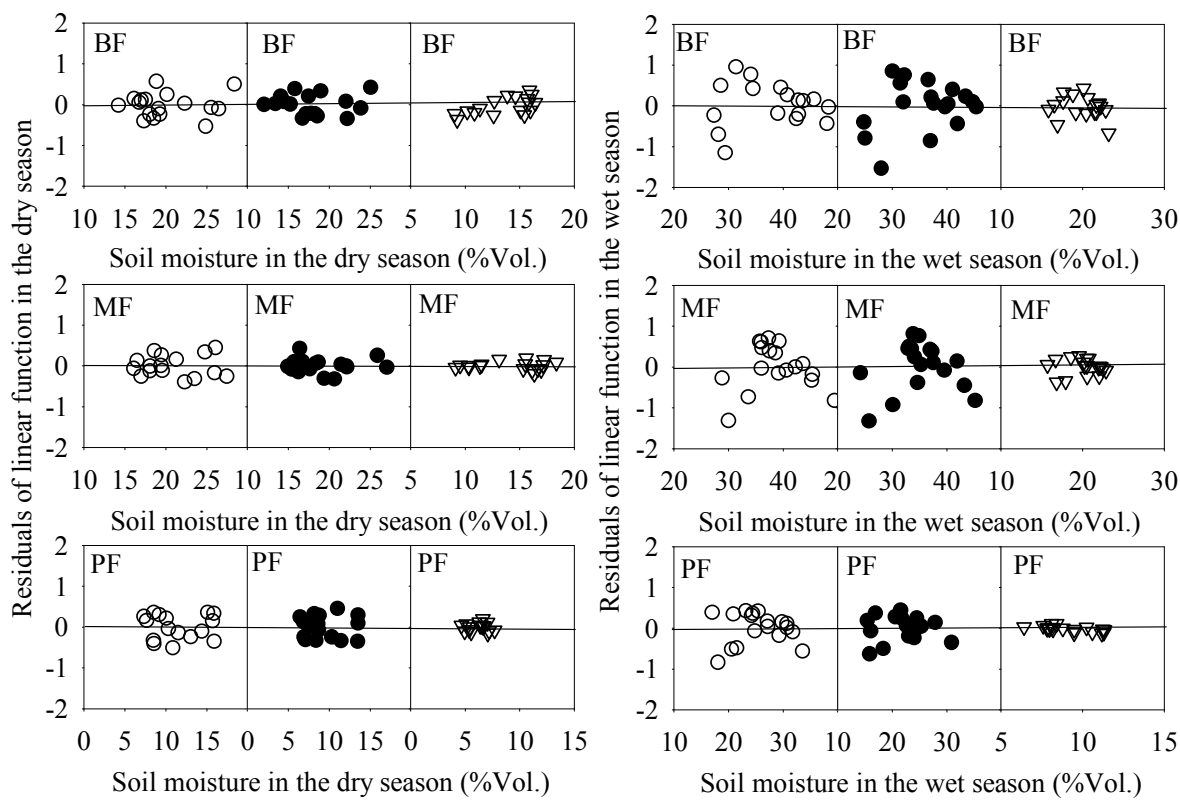

$\circ \quad \mathrm{DP} \quad-\mathrm{AP} \quad \nabla \quad \mathrm{EP}$

Fig. A4. Residual plots for the models of soil respiration rate $\left(R, \mu \mathrm{molCO} \mathrm{CO}_{2} \mathrm{~m}^{-2} \mathrm{~s}^{-1}\right)$ and soil temperature at $5 \mathrm{~cm}$ depth $\left(T\right.$, $\left.{ }^{\circ} \mathrm{C}\right)($ linear regression equation: $R=a+c M$ ) under different seasons and different precipitation treatments at the DNR forests. The treatments are as follows: precipitation exclusion (EP), ambient precipitation (AP), and double precipitation (DP). The forests are as follows: broadleaf forest $(\mathrm{BF})$, mixed forest (MF), and pine forest (PF).
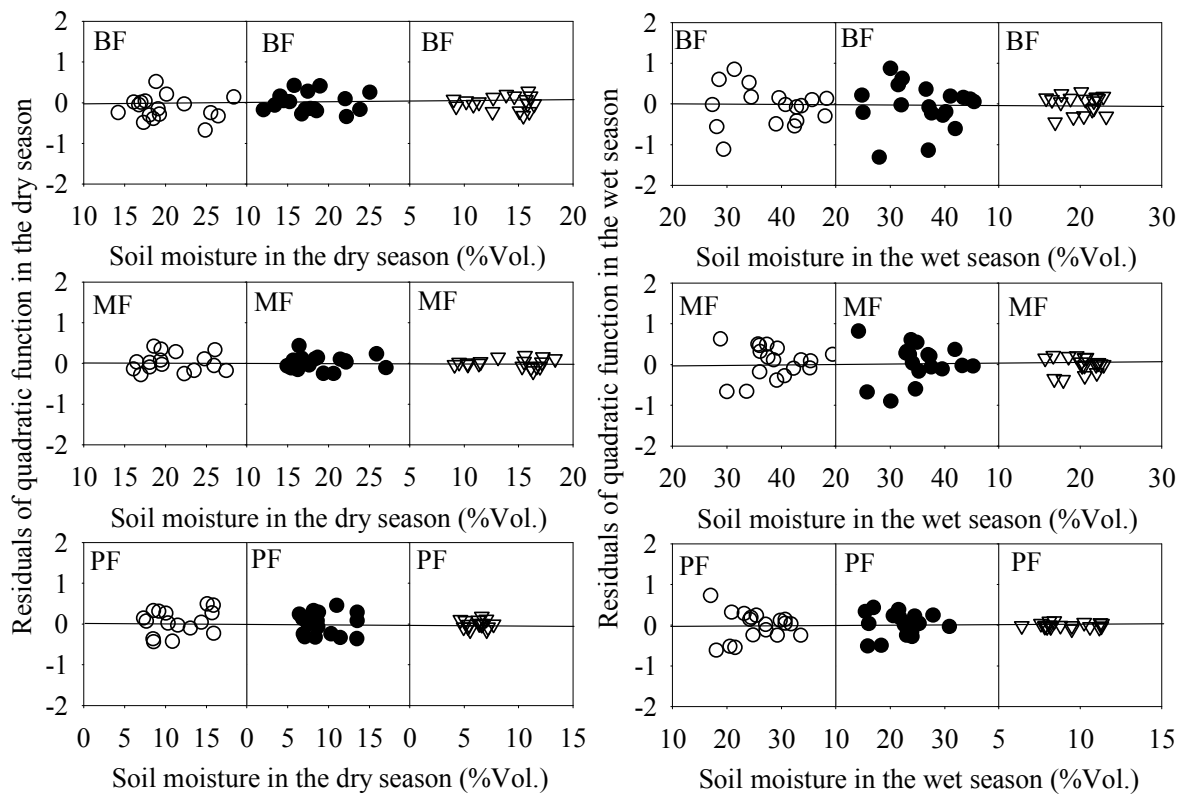

$\circ \quad \mathrm{DP} \quad \bullet \quad \mathrm{AP} \quad \nabla \quad \mathrm{EP}$

Fig. A5. Residual plots for the models of soil respiration rate $\left(R, \mu \mathrm{mol} \mathrm{CO} \mathrm{m}^{-2} \mathrm{~s}^{-1}\right)$ and soil moisture of the top $5 \mathrm{~cm}$ soil layer $(M, \%$ vol.) (quadratic equation: $R=a_{0} M^{2}+c_{0} M+d_{0}$ ) under different seasons and different precipitation treatments at the DNR forests. The treatments are as follows: precipitation exclusion (EP), ambient precipitation (AP), and double precipitation (DP). The forests are as follows: broadleaf forest $(\mathrm{BF})$, mixed forest $(\mathrm{MF})$, and pine forest $(\mathrm{PF})$. 
Table A4. Coefficient $\left(R^{2}\right)$ of measured soil respiration $(R)$ to soil temperature $(T)$ and moisture $(M)$ using different combined models at the DNR forests with control plots.

\begin{tabular}{|c|c|c|c|}
\hline \multirow[t]{2}{*}{ Functions } & \multicolumn{3}{|c|}{$R^{2}$} \\
\hline & $\mathrm{BF}$ & MF & $\mathrm{PF}$ \\
\hline \multicolumn{4}{|l|}{ Dry season } \\
\hline$R=\left(a_{1} M+c_{1}\right) e^{b_{1} T}$ & 0.93 & 0.87 & 0.81 \\
\hline$R=\left(a_{2} M^{2}+c_{2} M+d_{2}\right) e^{b_{2} T}$ & 0.93 & 0.87 & 0.82 \\
\hline$R=a_{3} c_{3}{ }^{M} e^{b_{3} T}$ & & & 0.83 \\
\hline \multicolumn{4}{|l|}{$R=a_{4} e^{b_{4} T}-\left(M-c_{4}\right)^{2}$} \\
\hline$R=a_{5} e^{b_{5} T} M /\left(M+c_{5}\right)$ & 0.91 & 0.70 & 0.84 \\
\hline$R=\left(a_{6} e^{c_{6} M}\right) e^{b_{6}(T-10)}$ & 0.91 & 0.87 & 0.83 \\
\hline$R=a_{7} \pm b_{7} W T$ & 0.79 & 0.71 & 0.85 \\
\hline \multicolumn{4}{|l|}{$R=a_{8} e^{b_{8} T}\left(M-M_{\min }\right)\left(M_{\max }-M\right)^{c_{8}}$} \\
\hline$R=a_{9} M^{c_{9}} T^{b_{9}}$ & 0.91 & 0.88 & 0.82 \\
\hline$R=\left(W /\left(a_{10}+W\right)\right)\left(b_{10} /\left(b_{10}+W\right)\right) c_{10} d_{10}(T+10) / 10$ & 0.73 & 0.63 & 0.76 \\
\hline \multicolumn{4}{|l|}{ Wet season } \\
\hline$R=\left(a_{1} M+c_{1}\right) e^{b_{1} T}$ & 0.95 & 0.98 & 0.89 \\
\hline$R=\left(a_{2} M^{2}+c_{2} M+d_{2}\right) e^{b_{2} T}$ & 0.96 & 0.98 & 0.90 \\
\hline$R=a_{3} c_{3}{ }^{M} e^{b_{3} T}$ & 0.92 & 0.87 & 0.74 \\
\hline \multicolumn{4}{|l|}{$R=a_{4} e^{b_{4} T}-\left(M-c_{4}\right)^{2}$} \\
\hline$R=a_{5} e^{b_{5} T} M /\left(M+c_{5}\right)$ & 0.93 & 0.87 & 0.75 \\
\hline$R=\left(a_{6} e^{c_{6} M}\right) e^{b_{6}(T-10)}$ & 0.92 & 0.86 & 0.74 \\
\hline$R=a_{7} \pm b_{7} W T$ & 0.90 & 0.87 & 0.75 \\
\hline \multicolumn{4}{|l|}{$R=a_{8} e^{b_{8} T}\left(M-M_{\min }\right)\left(M_{\max }-M\right)^{c_{8}}$} \\
\hline$R=a_{9} M^{c_{9}} T^{b_{9}}$ & 0.92 & 0.87 & 0.75 \\
\hline$R=\left(W /\left(a_{10}+W\right)\right)\left(b_{10} /\left(b_{10}+W\right)\right) c_{10} d_{10}^{(T+10) / 10}$ & 0.50 & 0.54 & 0.72 \\
\hline
\end{tabular}

Blank in the table indicated that we could not fit soil respiration to soil temperature and soil moisture using this combined model.
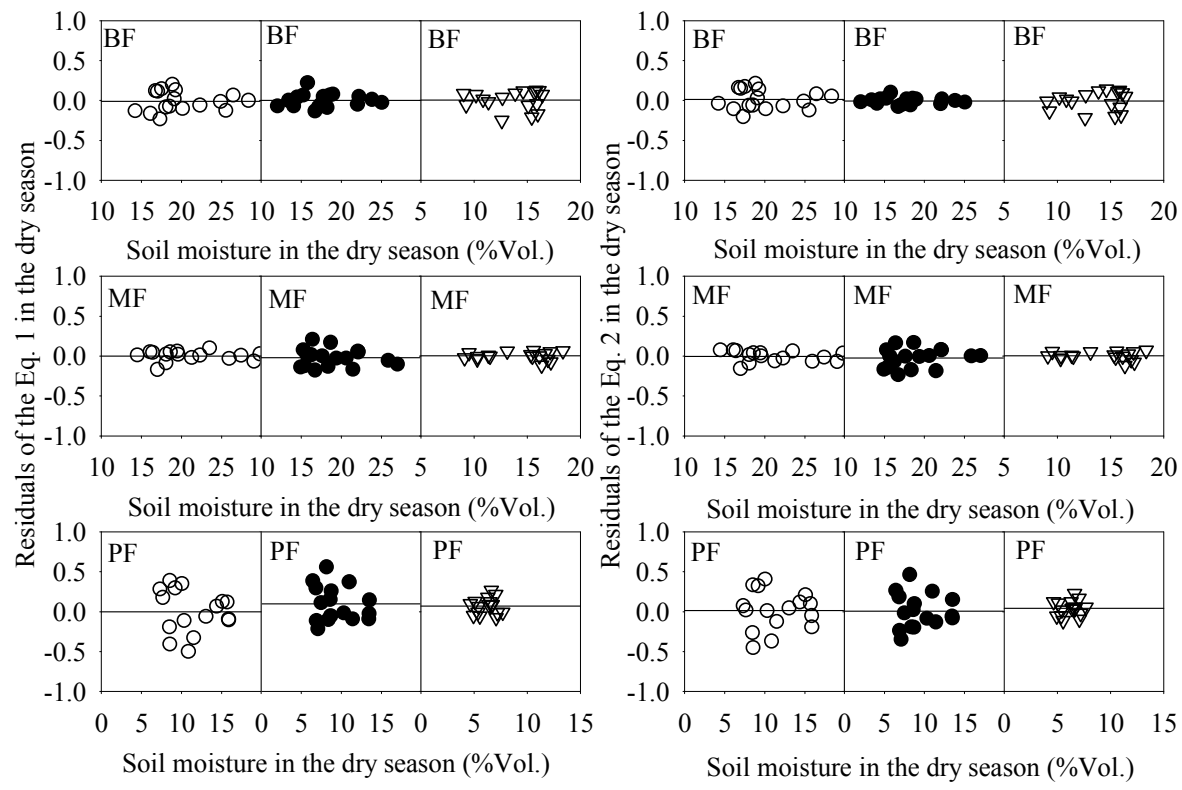

$\circ$ DP $\quad$ AP $\nabla$ EP

Fig. A6. Residual plots in the dry season for Eq. (1) $\left(R=\left(a_{1}+c_{1} M\right) \exp \left(b_{1} T\right)\right)$ and Eq. (2) $\left(R=\left(a_{2} M^{2}+c_{2} M+d_{2}\right) \exp \left(b_{2} T\right)\right)$ under different precipitation treatments at the DNR forests. The treatments are as follows: precipitation exclusion (EP), ambient precipitation (AP), and double precipitation (DP). The forests are as follows: broadleaf forest (BF), mixed forest (MF), and pine forest (PF). 

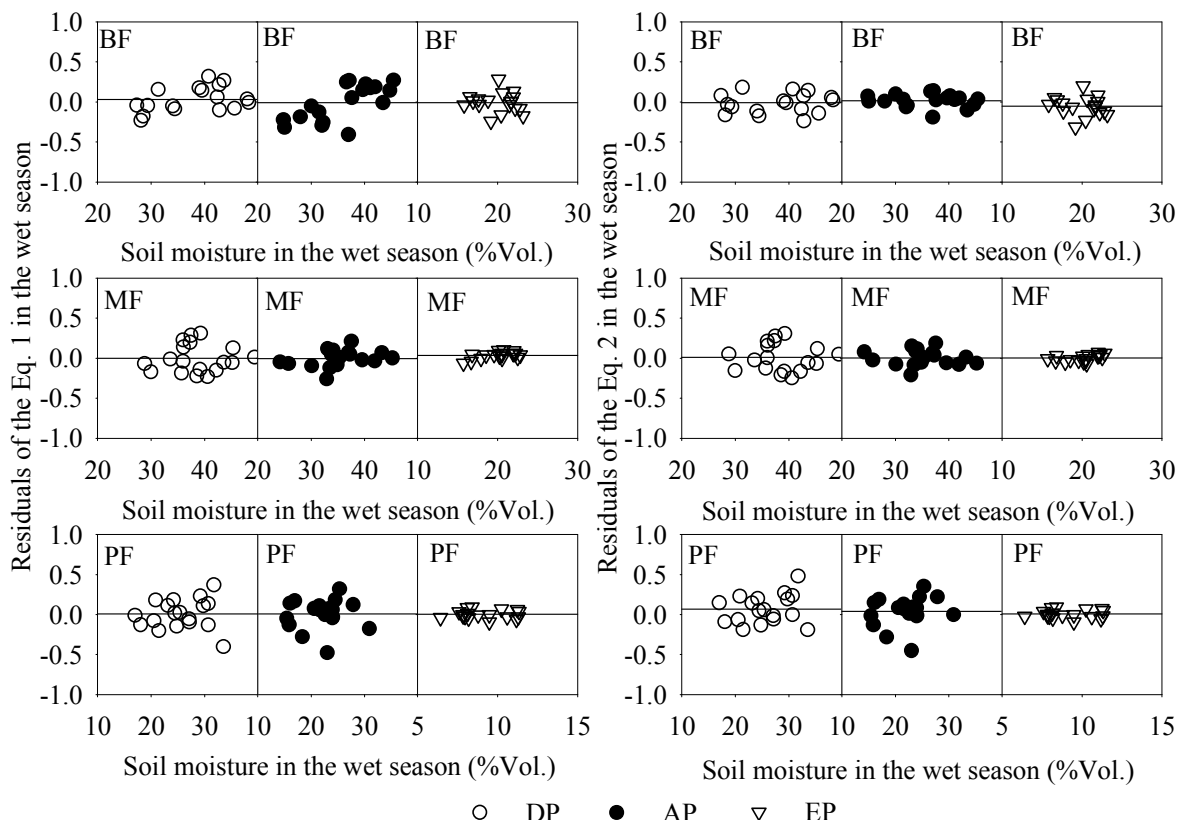

Fig. A7. Residual plots in the wet season for Eq. (1) $\left(R=\left(a_{1}+c_{1} M\right) \exp \left(b_{1} T\right)\right)$ and Eq. (2) $\left(R=\left(a_{2} M^{2}+c_{2} M+d_{2}\right) \exp \left(b_{2} T\right)\right)$ under different precipitation treatments at the DNR forests. The treatments are as follows: precipitation exclusion (EP), ambient precipitation (AP), and double precipitation (DP). The forests are as follows: broadleaf forest (BF), mixed forest (MF), and pine forest (PF).

Acknowledgements. This work was financially supported by National Basic Research Program of China (No. 2009CB42110x), Strategic Priority Research Program - Climate Change: Carbon Budget and Relevant Issues of CAS (XDA05050205), Dinghushan Forest Ecosystem Research Station, and the National Science Foundation (0933958).

Edited by: J. Xiao

\section{References}

Allan, R. P. and Soden, B. J.: Atmospheric Warming and the Amplification of Precipitation Extremes, Science, 321, 1481-1484, 2008.

Almagro, M., Lopez, J., Querejeta, J. I., and Martinez-Mena, M.: Temperature dependence of soil $\mathrm{CO}_{2}$ efflux is strongly modulated by seasonal patterns of moisture availability in a Mediterranean ecosystem, Soil Biol. Biochem., 41, 594-605, 2009.

Arrhenius, S.: The effect of constant influences upon physiological relationships, Scand. Arch. Physiol., 8, 367-415, 1898.

Asencio, D., Penuelas, J. L., Liusià, J., Ogaya, R., and Filella, L.: Interannual and interseasonal soil $\mathrm{CO}_{2}$ efflux and VOC exchange rates in a Mediterranean holm oak forest in response to experimental drought, Soil Biol. Biochem., 39, 2471-2484, 2007.

Bhupinderpal-Singh, Nordgren, A., Ottosson-Löfvenius, M., Högberg, M. N., Mellander, P-E., and Högberg, P.: Tree root and soil heterotrophic respiration as revealed by girdling of boreal Scots pine forest: extending observations beyond the first year, Plant Cell Environ., 26, 1287-1296, 2003.

Boddy, L: Carbon dioxide release from decomposing wood: Effect of water content and temperature, Soil Biol. Biochem., 5, 501-
510, 1983.

Bond-Lamberty, B. and Thompson, A.: Temperature-associated increases in the global soil respiration record, Nature, 464, 499500, 2010.

Borken, W., Savage, K., Davidson, E. A., and Trumbore, S.: Effects of experimental drought on soil respiration and radiocarbon efflux from a temperate forest soil, Glob. Change Biol., 12, 177193, 2006.

Bunnell, F. L., Tait, D. E. N., Flanagan, P. W., and van Cleve, K.: Microbial respiration and substrate weight loss. I. A general model of the influence of abiotic variables. Soil Biol. Biochem. 9, 3340, 1977.

Campbell, J. L., Sun, O. J., and Law, B. E.: Supply-side controls on soil respiration among Oregon forests, Glob. Change Biol., 10, 1429-1444, 2004.

Chou, W. W., Silver, W. L., Jackson, R. D., Thompson, A., and Alan-Diaz, B.: The sensitivity of annual grassland carbon cycling to the quantity and timing of rainfall, Glob. Change Biol., 14, 1382-1394, 2008.

Cleveland, C. C., Wieder, W. R., Reed, S. C., and Townsend, A. R.: Experimental drought in a tropical rain forest increases soil carbon dioxide losses to the atmosphere, Ecology, 91, 2313-2323, 2010.

Conant, R. T., Steinweg, J. M., Haddix, M. L., Paul, E. A., Plante, A. F., and Six, J.: Experimental warming shows that decomposition temperature sensitivity increases with soil organic matter recalcitrance, Ecology, 89, 2384-2391, 2008.

Cox, P. M., Betts, R. A., Jones, C. D., Spall, S. A., and Totterdell, I. J.: Acceleration of global warming due to carbon-cycle feedbacks in a coupled climate model, Nature, 408, 184-187, 2000.

Craine, J. M. and Gelderman, T. M.: Soil moisture controls on temperature sensitivity of soil organic carbon decomposition for a 
mesic grassland, Soil Biol. Biochem., 43, 455-457, 2011.

Curiel Yuste, J., Janssens, I. A., Carrara, A., Meiresonne, L., and Ceulemans, R.: Interactive effects of temperature and precipitation on soil respiration in a temperate maritime pine forest, Tree Physiol., 23, 1263-1270, 2003.

Curiel Yuste, J., Janssens, I. A., Carrara, A., and Ceulemans, R.: Annual $Q_{10}$ of soil respiration reflects plant phonological patterns as well as temperature sensitivity, Glob. Change Biol., 10, 161-169, 2004.

Curiel Yuste, J., Baldocchi, D. D., Gershenson, A., Goldstein, A., Misson, L., and Wong, S.: Microbial soil respiration and its dependency on carbon inputs, soil temperature and moisture, Glob. Change Biol., 13, 2018-2035, 2007.

Davidson, E. A. and Janssens, I.: Temperature sensitivity of soil carbon decomposition and feedbacks to climate change, Nature, 440, 165-173, 2006.

Davidson, E. A., Belk, E., and Boone, R. D.: Soil water content and temperature as independent or confounded factors controlling soil respiration in a temperate mixed hardwood forest, Glob. Change Biol., 4, 217-227, 1998.

Davidson, E. A., Verchot, L. V., Cattanio, J. H., Ackerman, I. L., and Carvalho, J. E. M.: Effects of soil water content on soil respiration in forests and cattle pastures of eastern Amazonia, Biogeochemistry, 48, 53-69, 2000.

Davidson, E. A., Janssens, I., and Luo, Y. Q.: On the variability of respiration in terrestrial ecosystems: moving beyond $Q_{10}$, Glob. Change Biol., 12, 154-164, 2006.

Davidson, E. A., Nepstad, D. C., Ishida, F. Y., and Brando, P. M.: Effects of an experimental drought and recovery on soil emissions of carbon dioxide, methane, nitrous oxide, and nitric oxide in a moist tropical forest, Glob. Change Biol., 14, 582-2590, 2008.

Deng, Q., Zhou, G., Liu, J., Liu, S., Duan, H., and Zhang, D.: Responses of soil respiration to elevated carbon dioxide and nitrogen addition in young subtropical forest ecosystems in China, Biogeosciences, 7, 315-328, doi:10.5194/bg-7-315-2010, 2010.

Deng, Q., Zhou, G. Y., Liu, J. X., Chu, G. W., and Zhang, D. Q.: Responses of soil $\mathrm{CO}_{2}$ efflux to precipitation pulses in Two Subtropical Forests in Southern China, Environ. Manag., 48, 11821188, 2011.

Deng, Q., Hui, D. F., Zhang, D. Q., Zhou, G. Y., Liu, J. X., Liu, S. Z., Chu, G. W., and Li, J.: Effects of precipitation increase on soil respiration: a three-year field experiment in subtropical forests in China, PloS One, 7, e41493, doi:10.1371/journal.pone.0041493, 2012.

Ding, M. M., Brown, S., and Lugo, A. E.: A continental subtropical forest in China compared with an insular subtropical forest in the Caribbean. General Technical Report IITF-17, USDA (United States Department of Agriculture) Forest Service, International Institute of Tropical Forestry, Río Piedras, Puerto Rico, 2001.

Doran, J. W., Mielke, I. N., Power, J. F.: Microbial activity as regulated by soil water filled pore space, in: Ecology of Soil Microorganisms in the Microhabital Environments, 94-99, Transactions of the 14th International Congress of Soil Science symposim-3, 1991.

Easterling, D. R., Meehl, G. A., Parmesan, C., Changon, S. A., Karl, T. R., and Mearns, L. O.: Climate extremes: Observations, modeling, and impacts, Science, 289, 2068-2074, 2000.
Espeleta, J. F. and Clark, D. A.: Multi-scale variation in fineroot biomass in a tropical rain forest: A seven-year study, Ecol Monog., 77, 377-404, 2007.

Falloon, P., Jones, C. D., Ades, M., and Paul, K.: Direct soil moisture controls of future global soil carbon changes: An important source of uncertainty, Global Biogeochem. Cy., 25, GB3010, doi:10.1029/2010GB003938, 2011.

Fang, C. and Moncrieff, J. B.: The dependence of soil $\mathrm{CO}_{2}$ efflux on temperature, Soil Biol. Biochem., 33, 155-165, 2001.

Gaumont-Guay, D., Andrew Black, T., Griffis, T. J., Barr, A. G., Jassal, R. S., and Nesic, Z.: Interpreting the dependence of soil respiration on soil temperature and water content in a boreal aspen stand, Agr. For. Meteorol., 140, 220-235, 2006.

Gulledge, J. and Schimel, J. P.: Controls on soil carbon dioxide and methane fluxes in a variety of Taiga forest stands in interior Alaska, Ecosystems, 3, 269-282, 2000.

Harper, C. W., Blair, J. M., Fay, P. A., Knapp, A. K., and Carlisle, J. D.: Increased rainfall variability and reduced rainfall amount decreases soil $\mathrm{CO}_{2}$ flux in a grassland ecosystem, Glob. Change Biol., 11, 322-334, 2005.

Heimann, M. and Reichstein, M.: Terrestrial ecosystem carbon dynamics and climate feedbacks, Nature, 451, 289-292, 2008.

Högberg, P. Nordgren, A., Buchmann, N., Taylor, A. F. S., Ekblad, A., Högberg, M. N., Nyberg, G., Ottosson-Löfvenius, M., and Read, D. J.: Large-scale forest girdling shows that photosynthesis drives soil respiration, Nature, 411, 749-752, 2001.

Holland, E. A. and Coleman, D. C.: Litter placement effects on microbial and organic matter dynamics in an agroecosystem, Ecology, 68, 425-433, 1987.

Holthausen, R. S. and Caldwell, M. M.: Seasonal dynamicas of root system respiration in Atriplex confertifolia, Plant Soil, 55, 307317, 1980.

Hui, D. F. and Luo, Y. Q.: Evaluation of soil $\mathrm{CO}_{2}$ production and transport in Duke Forest using a process-based modeling approach, Global Biogeochem. Cy., 18, GB4029, doi:10.1029/2004GB002297, 2004.

Ilstedt, U., Nordgren, A., and Malmer, A.: Optimum soil water for soil respiration before and after amendment with glucose in humid tropical acrisols and a boreal mor layer, Soil Biol. Biochem., 32, 1591-1599, 2000.

Intergovernmental Panel on Climate Change (IPCC): Climate Change 2007: The Physical Science Basis, edited by: Alley, R., Berntsen, T., Bindoff, N. L., Chen, Z. L., Chidthaisong, A., Friedlingstein, P., Gregory, J., Hegerl, G., Heimann, M., Hewitson, B., Hoskins, B., Joos, F., Jouzel, J., Kattsov, V., Lohmann, U., Manning, M., Matsuno, T., Molina, M., Nicholls, N., Overpeck, J., Qin, D., Raga, G., Ramaswamy, V., Ren, J., Rusticucci, M., Solomon, S., Somerville, R., Stocker, T. F., Stott, P., Stouffer, R. J., Whetton, P., Wood, R. A., and Wratt D., Contribution of Working Group I to the Fourth Assessment Report of the Intergovernmental Panel on Climate Change, Cambridge, UK and New York, USA, Cambridge University Press, 996 pp., 2007.

Janssens, I. A., Lankreijer, H., Matteucci, G., Kowalski, A. S., Buchmann, N., Epron, D., Pilegaard, K., Kutsch, W., Longdoz, B., Grünwald, T., Montagnani, L., Dore, S., Rebmann, C., Moors, E. J., Grelle, A., Rannik, Ü., Morgenstern, K., Oltchev, S., Clement, R., Guðmundsson J., Minerbi, S., Berbigier, P., Ibrom, A., Moncrieff, J., Aubinet M., Bernhofer, C., Jensen, N. O., Vesala, T. , Granier, A., Schulze, E.-D., Lindroth, A., 
Dolman, A. J., Jarvis, P. G., Ceulemans, R., and Valentini, R.: Productivity overshadows temperature in determining soil and ecosystem respiration across European forests, Glob. Change Biol., 7, 269-278, 2001.

Jassal, R. S., Black, T. A., Novak, M. D., and Gaumont-Guay Nesic, Z.: Effect of soil water stress on soil respiration and its temperature sensitivity in an 18-year-old temperate Douglas-fir stand, Glob. Change Biol., 14, 1-14, 2008.

Jenkinson, D. S.: The turnover of organic carbon and nitrogen in soil. Philos. T. Roy. Soc. Lond. B, 329, 361-368, 1990.

Joffre, R., Ourcival, J. M., Rambal, S., and Rocheteau, A.: The keyrole of topsoil moisture on $\mathrm{CO}_{2}$ efflux from a Mediterranean Quercus ilex forest, Ann. For. Sci., 60, 519-526, 2003.

Kirschbaum, M. U. F.: The temperature dependence of organic matter decomposition: seasonal temperature variations turn a sharp short-term temperature response into a more moderate annually averaged response, Glob. Change Biol., 16, 2117-2129, 2010.

Kucera, C. L. and Kirkham, D. R.: Soil respiration studies in tallgrass prairie in Missouri, Ecology, 52, 912-915, 1971.

Lavigne, M. B., Ryan, M. G., and Goodine, G.: Seasonal and annual changes in soil respiration in relation to soil temperature, water potential and trenchine, Tree Physiol., 17, 543-551, 2004.

Lima, T. T. S., Miranda, I. S., and Vasconcelos, S. S.: Effects of water and nutrient availability on fine root growth in eastern Amazonian forest regrowth, Brazil, New Phytol., 187, 622-630, 2010.

Liu, W., Zhang, Z., and Wan, S.: Predominant role of water in regulating soil and microbial respiration and their responses to climate change in a semiarid grassland, Glob. Change Biol., 15, 184-195, 2009.

Liu, X. Z., Wan, S. Q., Su, B., Hui, D. F., and Luo, Y. Q.: Response of soil $\mathrm{CO}_{2}$ efflux to water manipulation in a tallgrass prairie ecosystem, Plant Soil, 240, 213-223, 2002.

Lloyd, J. and Taylor, J. A.: On the temperature dependence of soil respiration, Funct. Ecol., 8, 315-323, 1994.

Luo, Y.: Terrestrial carbon cycle feedback to climate warming, Annu. Rev. Ecol. Evol. Syst., 38, 683-712, 2007.

Luo, Y. and Zhou, X.: Soil and Respiration Environment, Academic Press, San Diego, 2006.

Luo, Y., Wan, S., Hui, D., and Wallace, L. L.: Acclimatization of soil respiration to warming in a tall grass prairie, Nature, 413, 622-625, 2001

Medvigy, D., Wofsy, S. C., Munger, J. W., and Moorcroft, P. R.: Responses of terrestrial ecosystems and carbon budgets to current and future environmental variability, P. Natl. Acad. Sci. USA, 107, 8275-8280, 2010.

Mielnick, P. C. and Dugas, W. A.: Soil $\mathrm{CO}_{2}$ flux in a tallgrass prairie, Soil Biol. Biochem., 32, 221-228, 2000.

Misson, L., Rocheteau, A., Rambal, S., Ourcival, J.-M., Limousin, J.-M., and Rodriguez, R.: Functional changes in the control of carbon fluxes after 3 years of increased drought in a Mediterranean evergreen forest?, Glob. Change Ecol., 16, 2461-2475, 2010.

Moncrieff, J. B. and Fang, C.: A model for soil $\mathrm{CO}_{2}$ production and transport. 2. Application to a Florida Pinus elliottii plantation, Agr. Forest Meteorol., 95, 237-256, 1999.

Noormets, A., Desai, A., Cook, B. D., Ricciuto, D. M., Euskirchen, E. S., Davis, K., Bolstad, P., Schmid, H. P., Vogel, C. S., Carey, E. V., Su, H. B., and Chen, J. Q.: Moisture sensitivity of ecosystem respiration: comparison of 14 forest ecosystems in the Upper
Great Lakes Region, USA, Agr. Forest Meteorol., 148, 216-230, 2008.

O'Connell, A. M.: Microbial decomposition (respiration) of litter in eucalypt forests of southwestern Australia: an empirical model based on laboratory incubations, Soil Biol. Biochem., 22, 153160, 1990.

Orchard, V. A. and Cook, F. J.: Relationship between soil respiration and soil moisture, Soil Biol. Biochem., 15, 447-453, 1983.

Peng, S. L. and Wang, B. S.: Forest succession at Dinghushan, Guangdong, China, Chinese J. Bot., 7, 75-80, 1995.

Qi, Y., Xu, M., Wu, J.: Temperature sensitivity of soil respiration and its effects on ecosystem carbon budget: nonlinearity begets surprise, Ecol. Model., 153, 131-142, 2002.

Raich, J. W. and Potter, C. S.: Global patterns of carbon dioxide emissions from soils, Global Biogeochem. Cy., 9, 23-36, 1995.

Reichstein, M., Tenhunen, J. D., Roupsard, O., Ourcival, J.-M., Rambal, S., Dore, S., and Valentini, R.: Ecosystem Respiration in Two Mediterranean Evergreen Holm Oak Forests: Drought Effects and Decomposition Dynamics, Funct. Ecol., 16, 27-39, 2002.

Reichstein, M., Rey, A., Freibauer, A., Tenhunen, J., Valentini, R., Banza, J., Casals, P., Cheng, Y., Grünzweig, J. M., Irvine, J., Joffre, R., Law, B. E., Loustau, D., Miglietta, F., Oechel, W., Ourcival, J., Pereira, J. S., Peressotti, A., Ponti, F., Qi, Y., Rambal, S., Rayment, M., Romanya, Federica, J., Rossi, F., Tedeschi, V., Tirone, G., Xu, M., and Yakir, D.: Modeling temporal and largescale spatial variability of soil respiration from soil water availability, temperature and vegetation productivity indices, Global Biogeochem. Cy., 17, 1-15, 2003.

Reth, S., Graf, W., Reichstein, M., and Munch, J. C.: Sustained stimulation of soil respiration after 10 years of experimental warming, Environ. Res. Lett., 4, 024005, doi:10.1088/17489326/4/2/024005 2009.

Risch, A. C. and Frank, D. A.: Effects of increased soil water availability on grassland ecosystem carbon dioxide fluxes, Biogeochemistry, 86, 91-103, 2007.

Rochette, P., Desjardins, R. L., and Pattey, E.: Spatial and temporal variability of soil respiration in agricultural fields, Canad. J. Soil Sci., 71, 189-196, 1991.

Rustad, L. E., Huntington, T. G., and Boone, R. D.: Controls on soil respiration: Implications for climate change, Biogeochemistry, 48, 1-6, 2000.

Schlentner, R. E. and Van Cleve, K.: Relationships between $\mathrm{CO}_{2}$ evolution from soil, substrate temperature, and substrate moisture in four mature forest types in interior Alaska, Canad. J. Forest Res., 15, 156-165, 1985.

Schwendenmann, L. and Veldkamp, E.: The role of dissolved organic carbon, dissolved organic nitrogen, and dissolved inorganic nitrogen in a tropical wet forest ecosystem, Ecosystems, 8, 339351, 2005.

Shen, C. D., Liu, D. S., Peng, S. L., Sun, Y. M., Jiang, Z. T., Yi, W. X., Xin, C. P., Gao, Q. Z., Li, Z. A., and Zhou, G. Y.,: Distribution of ${ }^{14} \mathrm{C}$ and ${ }^{13} \mathrm{C}$ in forest soils of the Dinghushan Biosphere Reserve, Radiocarbon, 43, 671-678, 2001.

Sotta, E. D., Veldkamp, E., Schwendenmann, L., Guimarães, B. R., Paixão, R. K., De Lourdes, M., Ruivo, P., Da Costa, A. C. L., and Meir, P.: Effects of an induced drought on soil carbon dioxide $\left(\mathrm{CO}_{2}\right)$ efflux and soil $\mathrm{CO}_{2}$ production in an Eastern Amazonian rainforest, Brazil, Glob. Change Biol., 13, 2218-2229, 2007. 
Suseela, V., Conant, R., Wallenstein, M. D., and Dukes, J. S: Effects of soil moisture on the temperature sensitivity of heterotrophic respiration vary seasonally in an old-field climate change experiment, Glob. Change Biol., 18, 336-348, 2012.

Talmon, Y., Sternberg, M., and Grünzweig, J. M.: Impact of rainfall manipulations and biotic controls on soil respiration in Mediterranean and desert ecosystems along an aridity gradient, Glob. Change Biol., 17, 1108-1118, 2011.

Tang, X. L., Liu, S. G., Zhou, G. Y., Zhang, D. Q., and Zhou, C. Y.: Soil-atmospheric exchange of $\mathrm{CO}_{2}, \mathrm{CH}_{4}$, and $\mathrm{N}_{2} \mathrm{O}$ in three subtropical forest ecosystems in southern China, Glob. Change Biol., 12, 546-560, 2006.

Trumbore, S. E.: Potential responses of soil organic carbon to global environmental change, P. Natl. Acad. Sci. USA, 94, 8284-8291, 1997.

Valentini, R., Matteucci, G., Dolman, A. J., Schulze, E. D., Rebmann, C., Moors, E. J., Granier, A., Gross, P., Jensen, N. O., Pilegaard, K., Lindroth, A., Grelle, A., Bernhofer, C., Grnwald, T., Aubinet, M., Ceulemans, R., Kowalski, A. S., Vesala, T., Rannik, U., Berbigier, P., Loustau, D., Gumundsson, J., Thorgeirsson, H., Ibrom, A., Morgenstern, K., Clement, R., Moncrieff, J., Montagnani, L., Minerbi S., and Jarvis, P. G.: Respiration as the main determinant of carbon balance in European forests, Nature, 404, 861-865, 2000.

Vance, E. D., Brookes, S. A., and Jenkinson, D. S.: An extraction method for measuring soil microbial biomass C, Soil Biol. Biochem., 19, 703-707, 1987.

van Straaten, O., Veldkamp, E., Köhler, M., and Anas, I.: Spatial and temporal effects of drought on soil $\mathrm{CO}_{2}$ efflux in a cacao agroforestry system in Sulawesi, Indonesia, Biogeosciences, 7, 1223-1235, doi:10.5194/bg-7-1223-2010, 2010.

van Straaten, O., Veldkamp, E., Köhler, M., and Anas, I.: Simulated drought reduces soil $\mathrm{CO}_{2}$ efflux and production in a tropical forest in Sulawesi, Indonesia, Ecosphere, 2, 119, doi:10.1890/ES11$00079.1,2011$.

Van't Hoff, J. H.: Etudes de dynamique chimique (studies of Chenmical dynamics), Frederik Muller and Co, Amsterdam, the Netherlands, 1884.

Wang, B. S. and Ma, M. J.: The successions of the forest community in Dinghushan, Trop. Subtrop. For. Ecosyst. Res., 1, 142-156, 1982.

Wang, X. H., Piao, S. L., Ciais, P., Janssens, I. A., Reichstein, M., Peng, S. S., and Wang, T.: Are ecological gradients in seasonal $\mathrm{Q}_{10}$ of soil respiration explained by climate or by vegetation seasonality?, Soil Biol. Biochem., 42, 1728-1734, 2010.
Wildung, R. E., Garland, T. R., and Buschbom, R. L.: The interdependent effects of soil temperature and water content on soil respiration rate and plant root decomposition in arid grassland soils, Soil Biol. Biochem., 7, 373-378, 1975.

Williams, M. A.: Response of microbial communities to water stress in irrigated and drought-prone tallgrass prairie soils, Soil Biol. Biochem., 39, 2750-2757, 2007.

Wu, H., Deng, H., and Zheng, L: Physico-geographical features of Dinghushan and their dynamic analyses, Trop. Subtrop. For. Ecosyst. Res., 1, 1-10, 1982.

$\mathrm{Xu}, \mathrm{M}$. and Qi, Y.: Spatial and seasonal variations of $Q_{10}$ determined by soil respiration measurements at a Sierra Nevadan forest, Global Biogeochem. Cy., 15, 687-697, 2001.

Yan, J. H., Zhang, D. Q., Zhou, G. Y., and Liu, J. X.: Soil respiration associated with forest succession in subtropical forests in Dinghushan Biosphere Reserve, Soil Biol. Biochem., 9, 1-9, 2009.

Yuste, J. C., Penuelas, J., Estiarte, M., Garcia-Mas, J., Mattana, S., Ogaya, R., Pujol, M., and Sardans, J.: Drought-resistant fungi control soil organic matter decomposition and its response to temperature, Glob. Change Biol., 17, 1475-1486, 2011.

Zhang, D. Q., Sun, X. M., Zhou, G. Y., Yan, J. H., Wang, Y. S., Liu, S. Z., Zhou, C. Y., Tang, X. L., Li, J., and Zhang, Q. M.: Seasonal dynamics of soil $\mathrm{CO}_{2}$ effluxes with responses to environmental factors in lower subtropical forest of China, Sci. China Ser. D, 49, 139-149, 2006.

Zhang, W., Parker, K., Luo, Y., Wan, S., Wallace, L. L., and Hu, S.: Soil microbial responses to experimental warming and clipping in a tallgrass prairie, Glob. Change Biol., 11, 266-77, 2005.

Zhou, G. Y., Wei, X. H., Liu, S. G., Huang, Y. H., Yan, J. H., Zhang, D. Q., Zhang, Q. M., Liu, J. X., Meng, Z., Wang, C. L., Chu, G. W., Liu, S. Z., Tang, X. L., and Liu, X. D.: Quantifying responses of hydrological processes to climate change using an intact forested watershed in Southern China, Glob. Change Biol., 17, 3736-3746, 2011.

Zhou, X. H., Sherry, R. A., An, Y., Wallace, L. L., and Luo, Y. Q.: Main and interactive effects of warming, clipping, and doubled precipitation on soil $\mathrm{CO}_{2}$ efflux in a grassland ecosystem, Global Biogeochem. Cy., 20, GB1003, doi:10.1029/2005GB002526, 2006.

Zogg, G. P., Zak, D. R., Ringelberg, D. B., White, D. C., MacDonald, M. W., and Pregitzer, K. S: Compositional and functional shifts in microbial communities due to soil warming, Soil Sci. Soc. Am. J., 61, 475-481, 1997. 